\title{
Legature, intrecci e merletti. Le strutture tessili
}

\author{
Sara Conte \\ Michela Rossi \\ Valentina Marchetti \\ Giorgio Buratti
}

Abstract

Uno dei problemi tecnici fondamentali del progetto riguarda la connessione delle parti che costituiscono gli artefatti. In questo senso l'arte della tessitura presenta aspetti di interesse applicabili nel campo del design e dell'architettura, che dimostrano, alla luce degli effetti dell'ultima rivoluzione digitale, l'attualità delle affermazioni di Semper nella classificazione dei materiali e delle tecniche costruttive.

A partire dallo studio dello stato dell'arte e delle tecniche tradizionali di realizzazione del merletto milanese, la ricerca propone la digitalizzazione e parametrizzazione del suo processo costruttivo. La valorizzazione della tecnica tradizionale è finalizzata alla reinvenzione produttiva applicata al design di nuovi materiali strutturali, piuttosto che alla mera conservazione del manufatto storico o al suo adeguamento estetico al gusto contemporaneo.

La modellazione generativa offre una valida soluzione di digitalizzazione e reinterpretazione del procedimento reiterato di produzione del merletto. Una volta definiti gli elementi di base, i movimenti d'intreccio o annodatura e il ciclo completo da ripetere, si può ricreare la struttura formale mediante il controllo geometrico dei parametri di forma e movimento. La sperimentazione dimostra come i nuovi strumenti di progettazione e produzione offrano la possibilità di sviluppare soluzioni innovative legate alla manipolazione dei parametri formali.

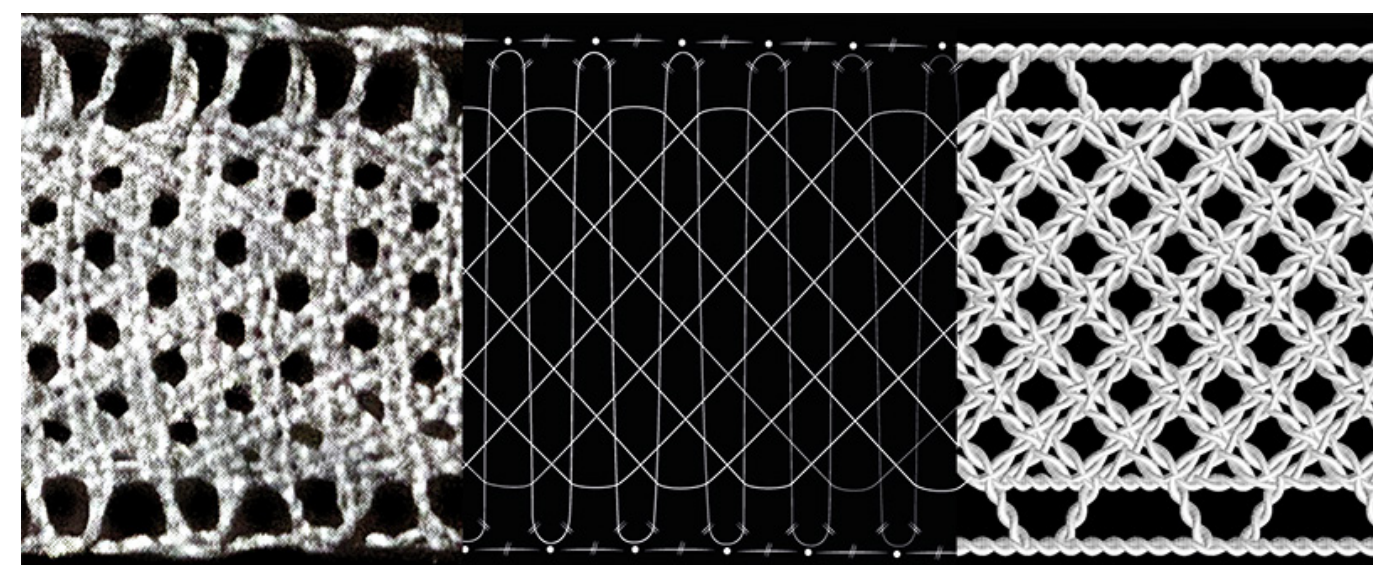




\section{Introduzione. Le premesse teoriche}

Gottfried Semper sostiene che l'architettura abbia imparato le regole dello stile dalle forme degli oggetti d'uso e oggi possiamo dire che in seguito, quando la produzione industriale ha sostituito l'artigianato e l'ideatore si è separato dall'artefice richiedendo un progetto preordinato, questa le ha restituite al design. I principi formali che reinterpretano leggi e forze naturali (simmetria, proporzione, movimento) si riflettono nelle tre forme essenziali della tessitura (festone, bordo, nastro) che caratterizzano sia l'abbigliamento che l'architettura, nella quale il principio del rivestimento, sottolineato dalla comune radice delle parole wand e gewand (parete e veste), si associa al principio costruttivo che permette di creare strutture spaziali solidali legando pezzi di dimensioni ridotte.

Il nodo e l'intreccio da cui nascono il bottone e la cucitura, la tessitura e il merletto, sono elementi costruttivi e decorativi insieme. L'intreccio e il merletto rielaborano la legatura tridimensionale del nodo: un movimento della fune nello spazio, che con avvolgimenti o accavallamenti rende solidali due monconi. II nodo fissa l'inizio di strutture allungate (trecce) che a loro volta possono generare stuoie e tessuti, nei quali la regolarità ricorsiva costituisce il principale elemento di ordine e di resistenza e permette la creazione di disegni caratteristici. L'articolazione dei segni dell'intreccio/annodatura di refoli a più direzioni determina sulla superficie un disegno che scaturisce dal materiale e diventa forma, coniugando i principi della costruzione e dell'ornamento.

II nodo, l'intreccio e la tessitura sviluppano la logica modulare e le regole geometriche della superficie, che insieme alle simmetrie dello spazio costituiscono un tema di ricerca teorico (matematica) e progettuale (design): le strutture geometriche dell'ornato ci portano alle griglie modulari e alle simmetrie dei reticoli alla base delle costruzioni spaziali e alle regole della tassellazione piana e tridimensionale indagate da Escher, Fuller e Penrose, sottolineando l'importanza del principio tessile nell'architettura e il suo stretto rapporto con le arti applicate.

Le innumerevoli scale di applicazione dei principi formali del nodo, dell'intreccio e del tessuto e la loro rielaborazione volta all'applicazione in molteplici campi rappresentano una fonte preziosa di riferimenti per la trasposizione a differenti scale e con l'uso di altri materiali. Oggi l'applicazione degli strumenti della civiltà digitale e le loro grandi potenzialità produttive riaffermano l'importanza dei principi costruttivi primari, sottolineando l'importanza di rivedere i concetti e gli elementi elementari della tessitura nell'ottica dell'innovazione digitale. Dalla tradizione cinquecentesca del merletto milanese, della quale resta traccia nei pizzi di Cantù e nelle pubblicazioni di Gio Ponti, inizia una ricerca che intende sperimentare strutture generate da algoritmi digitali applicabili alla realizzazione di materiali e manufatti innovativi e sostenibili reinterpretando un'arte antica attraverso strumenti e tecnologie digitali.

\section{La tradizione e la rilettura novecentesca}

Secondo una leggenda veneziana, il primo merletto fu realizzato in schiuma di mare e donato dalle sirene a un pescatore dell'isola di Burano come premio per la fedeltà dimostrata verso la fidanzata. La storia svela l'origine del merletto, che evolve a partire dalle reti da pesca divenendo oggetto decorativo: le donne infatti ne affinano la trama studiando figure e geometrie ricercate.

Tra la fine del XV e l'inizio del XVI secolo il merletto ad aghi di Burano si diffonde nelle case signorili. Inoltre, nei documenti di divisione dei beni tra le sorelle Angela e Ippolita Sforza Visconti (I493), si utilizza il termine 'tarnete' per indicare trecce, pizzi e passamaneria, testimoniando la loro presenza anche in area del milanese e dal I584 il merletto risulta tra gli insegnamenti dell'Università dei ricamatori di Milano. Nella seconda metà del XVII secolo la tecnica del merletto trova ampia diffusione grazie all'affermarsi, nel monastero di Santa Maria a Cantù, dellinsegnamento a gruppi di ragazze dell'uso del tombolo a fuselli. Questa pratica e la tecnica canturina si diffusero poi in varie scuole tra cui La Regia scuola d'arte applicata all'industria locale fondata nel 1882. 
Dopo la battuta d'arresto causata dalla Prima Guerra Mondiale e in opposizione alla diffusione dei pizzi realizzati a macchina, le attività artigianali e industriali vengono rilanciate dall'ENAPI e presto i lavori tessili entrano a far parte prima delle biennali di Monza e poi delle triennali, attirando l'attenzione di vari architetti tra i quali Gio Ponti. Domus, Stile e Fili, nate nel 1934 per volontà di Emilia Kuster Rosselli, contribuiscono in modo significativo alla diffusione e modernizzazione del merletto. Domus fornirà accurate rassegne della sezione dedicata a pizzo e ricamo alla Triennale del 1933, promuovendo la preparazione della Triennale del 1940, nata "con lo scopo preciso di realizzare [...] la più esauriente e alta mostra moderna del ricamo, che siasi mai vista in Italia" [Ponti 1939, p. 65, 66]. A partire dal 1928 sono pubblicati vari esempi di merletti 'moderni' tra cui quelli disegnati dall'architetto G. Wenter Marini, direttore dal 1931 della Scuola canturina del mobile e del merletto. Le ricerche degli anni '30 si focalizzano sull'astrazione e la geometrizzazione del disegno, senza modifiche significative in termini materici; solo a partire dalla fine degli anni '50, dopo la nuova battuta d'arresto della guerra assistiamo da un lato alla diffusione di merletti e centrini realizzati in plastica, dove l'innovazione consiste solo nell'applicazione del nuovo materiale, e dall'altro a diversificate sperimentazioni che reinterpretano la tecnica pratica tradizionale discostandosene. Nel 1965 La Tenda di Carla Accardi crea un ambiente 3D in sicofoil, arricchito da una fitta trama di segni grafici, che rimanda alla tradizionale tecnica d'intreccio reinterpretata attraverso la grafica e il colore. Altri lavori interessanti sono sviluppati da Franca Sonnino a partire dalla seconda metà degli anni '70, dove gli intrecci di fil di ferro e filo di cotone ricreano libri tridimensionali, elementi costruttivi come mattoni, mosaici o rappresentazioni tridimensionali astratte dell'architettura.

Dai primi anni '90 proliferano iniziative per la salvaguardia della tradizione del merletto come la Biennale Internazionale del Merletto di Cantù e la correlata Merletti e Design, che vedono la collaborazione tra artisti, architetti, designer e merlettaie per dar vita a progetti innovativi che valorizzino la sapienza artigianale, inserendola nelle ricerche del design contemporaneo [Guglielmetti 20 I5], culminate con la candidatura dello stesso per l'inserimento nella lista dei beni del Patrimonio Culturale Immateriale dell'Unesco. Negli ultimi I0 anni la ripresa delle tecniche tradizionali e dell'estetica del merletto si combina alle nuove tecnologie. Serena Confalonieri presenta nel 2014 due lampade che sfruttano le tecnologie $3 \mathrm{D}$ reinterpretando gli intrecci tipici dei merletti e dell'oreficeria tradizionale italiana in poliammide sinterizzato; schemi preordinati e ripetuti tipici del merletto sono alla base degli elementi architettonici della macro-installazione di The Flying Mosque di Choi+Shine Archi-

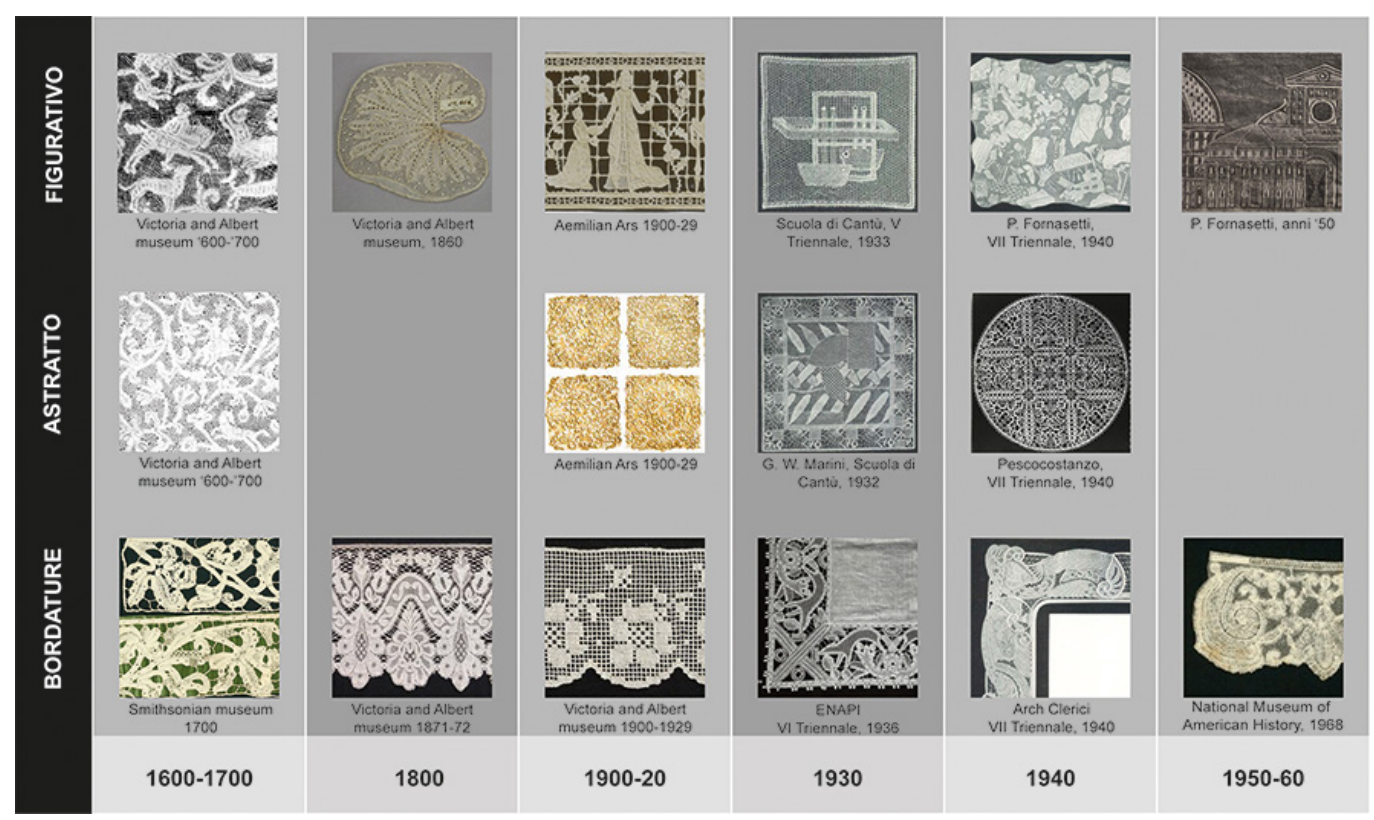


tects del 2018 e infine Lisa Marks progetta un reggiseno per donne mastectomizzate, nel quale la modellazione algoritmica genera un merletto tridimensionale, in grado di adattarsi a qualsiasi forma anatomica: il merletto diventa struttura.

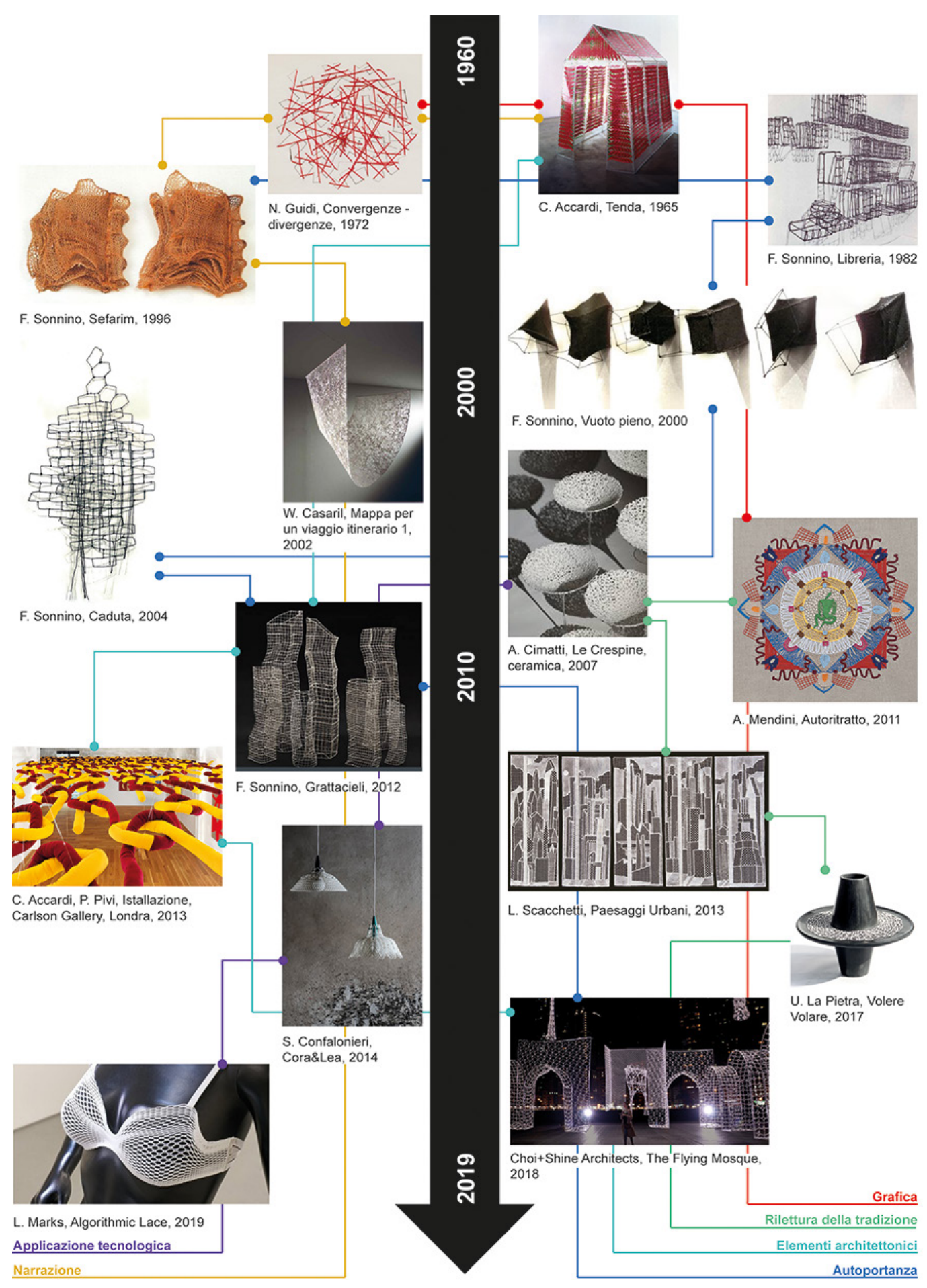




\section{Il tombolo e la tecnica lombarda del merletto milanese}

II merletto a tombolo è un'opera tessile eseguita a mano, realizzata intrecciando alcuni fili singoli parzialmente avvolti su bobine alle estremità, comunemente chiamate fuselli. L'intreccio viene lavorato su un cuscino di forma cilindrica imbottito di crine da cui prende il nome, il tombolo, e a cui è fissato attraverso spilli che ne bloccano anche i vari passaggi durante l'avanzamento del lavoro. I filati di uso tradizionale sono il lino, la seta, il cotone, o più particolari fili metallici, mentre nelle creazioni moderne si usano materiali di ogni genere. Dal punto di vista della tecnica viene distinto in:

- merletto a filo continuo, lavorato sia nelle parti piene e in quelle vuote, chiamate retini, partendo da un numero costante, a volte elevato, di fuselli;

- merletto a nastrino continuo, eseguito con un numero limitato e costante di coppie, dove il nastrino, costituisce la parte piena del lavoro seguendo un disegno di volute più o meno elaborate; quando diverse parti si avvicinano vengono unite per mezzo di passaggi di filo, a uncinetto o a fuselli, chiamati barrette o con retini a disegni più complessi;

- merletto a nastrino discontinuo o a pezzi riportati, utilizza invece un numero variabile di fuselli che aumenta o diminuisce nel corso del lavoro seguendo il disegno; le parti piene che possono essere eseguite da persone diverse, vengono unite con l'uncinetto e riempite nelle parti vuote da fondi a trecce, barrette o retini.

Fin dalle origini nel $X V$ secolo, la caratteristica principale della trina a fuselli di area lombarda, il merletto milanese o punto Milano, è la tecnica del nastrino o bisetta, definibile merletto delle origini data la presenza di numerosi disegni per questa tecnica in uno dei primi e più diffusi libri di modelli per trine Le Pompe, stampato a Venezia nel I557. La tessitura è compatta e solida, di esecuzione abbastanza veloce, che ne determina il successo nel tempo. Nei merletti più antichi giunti a noi, a differenza dei merletti fiamminghi coevi, il nastrino è continuo e disegna fiori e fogliame con motivi ornamentali tradizionali. A differenza delle trine ad ago esso non necessita una rete di fondo a supporto della lavorazione e i motivi sono uniti tra loro per mezzo di barrette a treccino nel corso della lavorazione [Jourdain 1905]. A partire dalla metà del Seicento nelle lavorazioni compare la rete di fondo, eseguita a partire dalla lavorazione e non applicata a posteriori, con i medesimi punti base per riempire gli spazi con motivi a ragnatela, pesce, gelosia o a Valenciennes. II merletto è realizzato seguendo procedure tecnico-stilistiche definite: una disegnatrice riporta un disegno su cartoncino creando il progetto grafico; successivamente la spuntatrice, seguendo l'andamento della tessitura, fora il disegno che servirà da tracciato alla merlettaia per la realizzazione dell'intreccio (fig. 3).

Fig. 3. Disegno schematico del motivo in cui le barre trasversali indicano il numero di girate de filato, i punti indicano gli spilli, i cerchi il punto torto; cartone spuntato; il motivo realizzato.
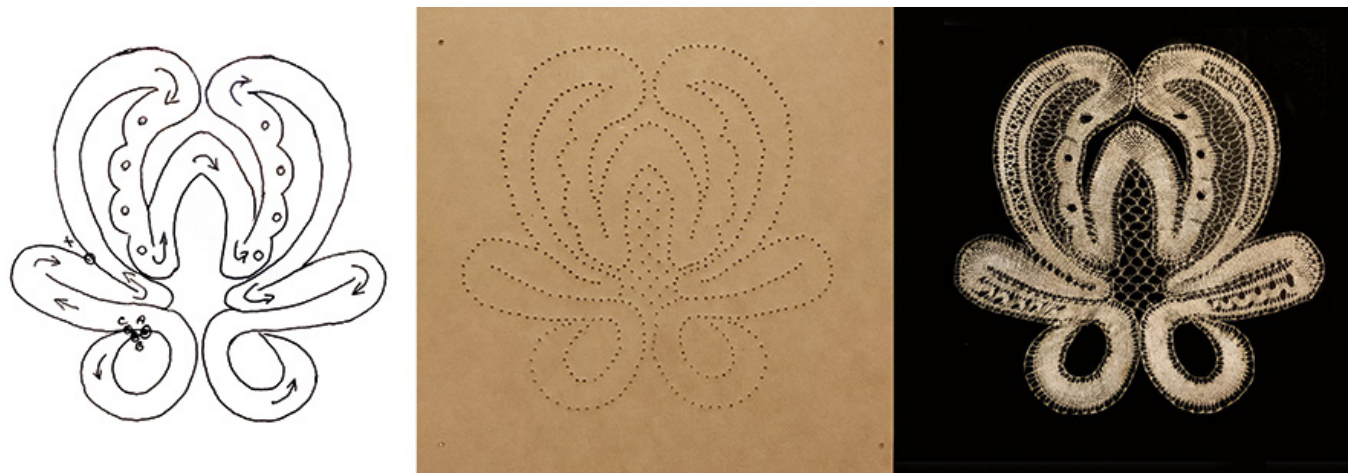

Allinizio del disegno vengono ancorate in linea alcune coppie di fuselli, solitamente in numero dispari, chiamate verticali, mentre la coppia portante posizionata più in basso rispetto alle verticali, viene lavorata alternativamente da una parte all'altra creando il nastrino [Read, Kindcaid 1988]. 
Fig. 4. Tre movimenti del punto tessuto o punto pieno I/G/I a) due coppie di fuselli, b) il secondo filo della coppia sinistra incrocia il primo filo della coppia destra c) contemporaneamente contio di posizione tra second flo e primo filocondo plio e primo flo coppia sinistra e tra il secondo filo e primo

filo coppia destra d) il

secondo filo della coppia

sinistra incrocia il primo filo della coppia destra.

Fig. 5. Due movimenti del mezzo punto $G / l$ a) due coppie di fuselli, b) contemporaneamente scambio di posizione tra secondo filo e primo filo coppia sinistra e tra secondo filo e primo filo coppia destra c) il secondo filo della coppia sinistra incrocia il primo filo della coppia destra.

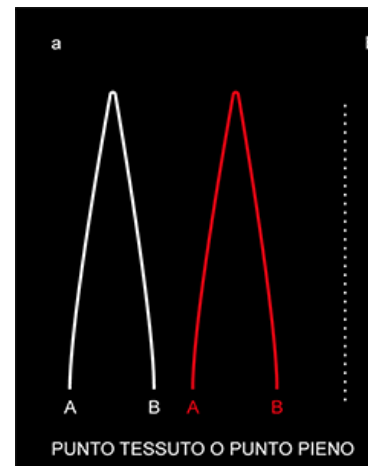
INCROCIO GIRATA INCROCIO
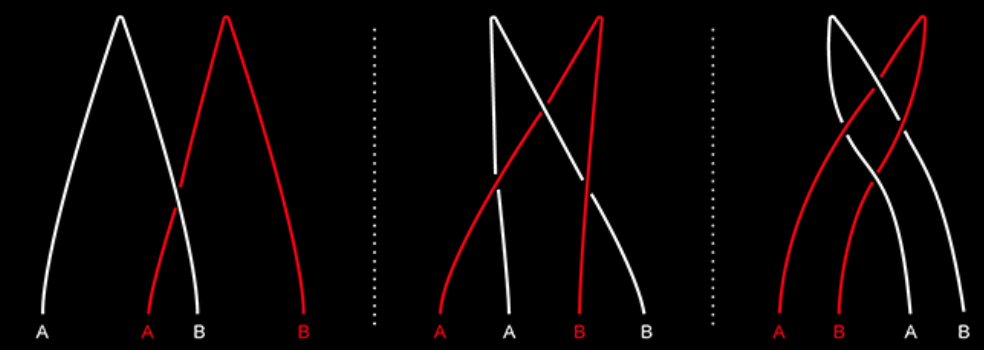

PUNTO TESSUTO O PUNTO PIENO

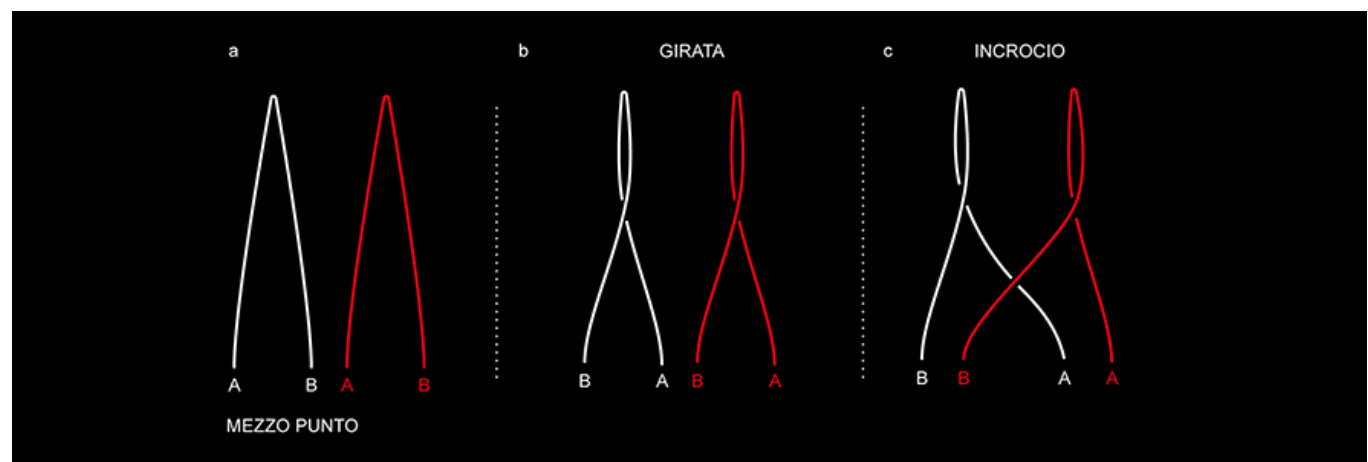

Fig. 6. Cinque movimenti del punto torto $/ / G / / / G / 1$

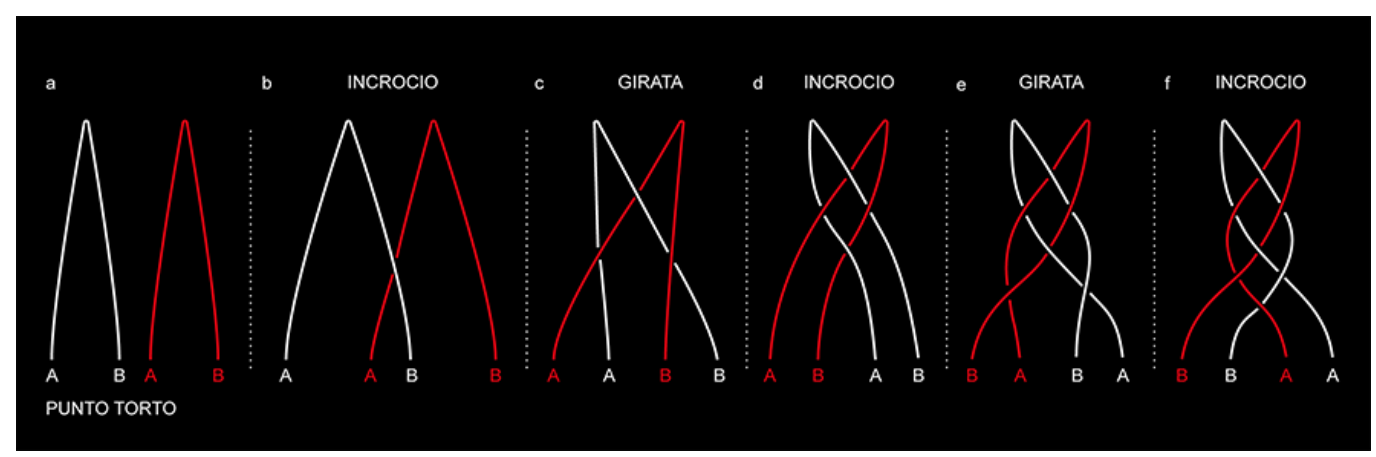


Tutti i punti base della tessitura si originano dall'utilizzo di due coppie di fuselli, il portante e un verticale, lavorando con movimenti di girata, scambio della posizione dei fili in una stessa coppia, e d'incrocio, con lo scambio di posizione tra i fili affiancati di due coppie diverse (figg. 4-7).

La combinazione e successione di sequenze codificate dei punti tessuto o punto pieno, mezzo punto e punto torto con spazi vuoti danno vita nel merletto milanese a una grande varietà di motivi, circa 80 , rispetto a qualsiasi altro pizzo. La varietà, le caratteristiche autoportanti del tessuto, la tridimensionalità del processo d'intreccio decorativo e le sperimentazioni in atto hanno permesso la generazione automatizzata di un nastrino [Read, Kindcaid 1994] tradizionale, favorendo l'applicazione di queste strutture in vari campi del design.

Fig. 7. a) La coppia di fili portanti passa attraverso tutti i verticali con uno Alla fine della riga una. doppia torsione del por doppia torsione del pordello spllo, penamento dello spillo, permetto di ripartire con il lavoro.; b) In questo punto un solo filo della coppia portante passa attraverso tutte le coppie verticali che s'incrociano, formando un disegno piu aperto ad esagoni. Alla fine della riga una torsione singola del portante, $i$ posizionamento dello spillo, permettono di ripartire con il lavoro.

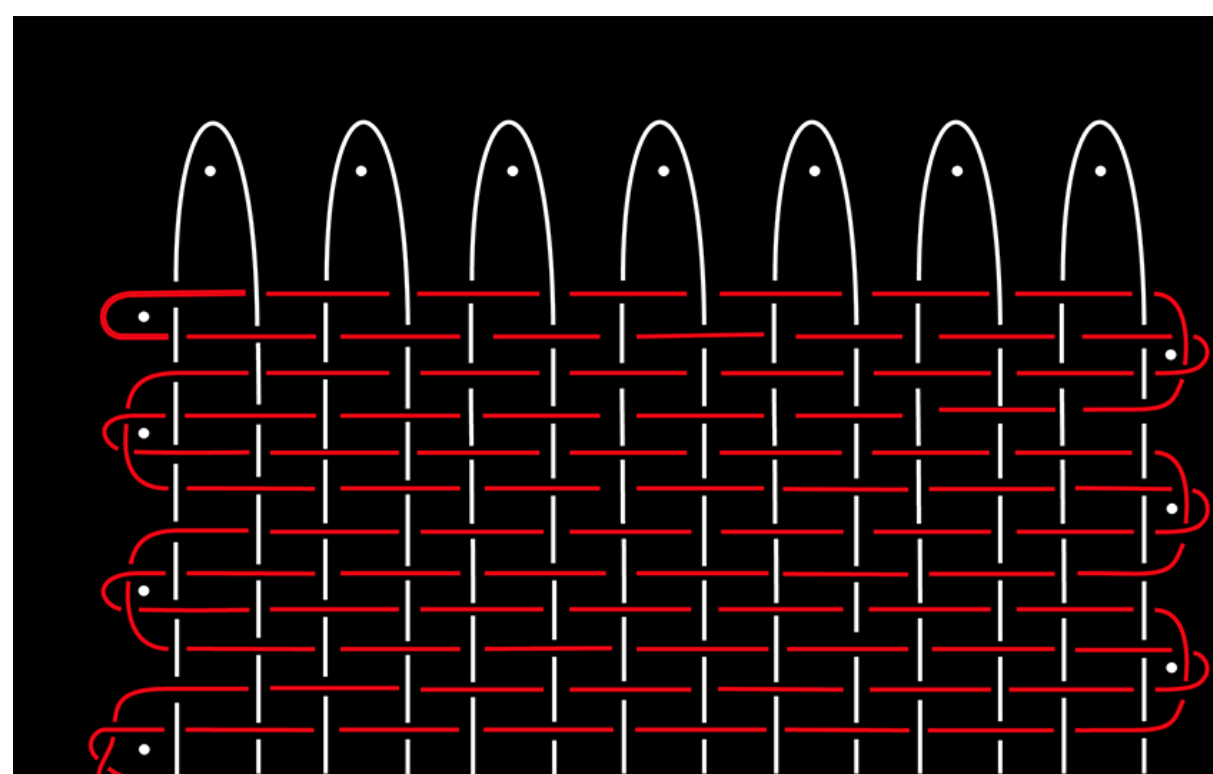

a_ SCHEMA DI UN NASTRINO A 8 COPPIE IN PUNTO TESSUTO

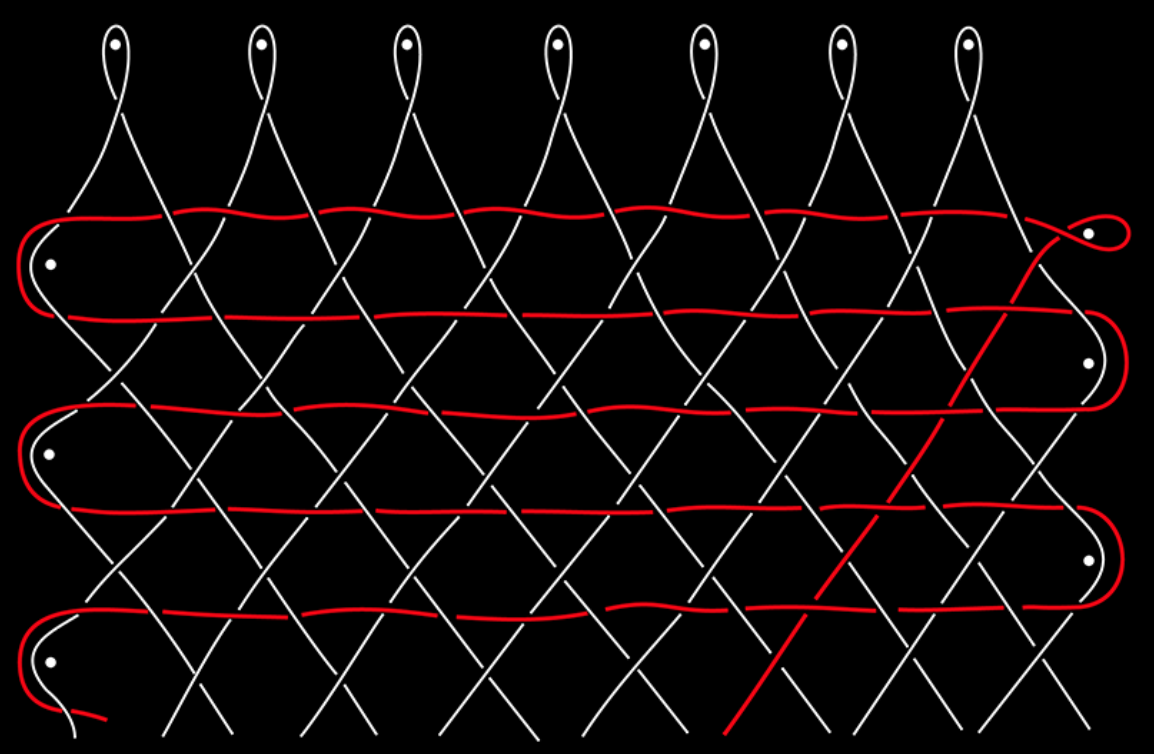

b SCHEMA DI UN NASTRINO A 8 COPPIE IN MEZZO PUNTO 


\section{Merletti digitali}

II binomio processi computazionali e produzione tessile ha attirato l'interesse del mondo industriale e di quello accademico sin dall'invenzione (XVII sec.) del telaio Jacquard, che permetteva la movimentazione automatica dei singoli fili di ordito a partire da cartoni perforati per impostare trame più complesse di quelle ottenibili a mano. La tecnologia ha dato un notevole impulso al settore tessile: il computational textile [Xianyi et al. 2007], ha permesso soluzioni capaci di migliorare le proprietà di lavabilità ed elasticità promuovendo nuove funzionalità. II risultato è l'attuale varietà di tessili avanzati le cui proprietà discendono dalla sinergia tra materiali innovativi utilizzati e lo studio delle geometrie che ne caratterizzano l'intreccio.

Rappresentare mediante algoritmi le morfologie tessili significa capirne le combinazioni e le sequenze di nodi caratteristiche, per tradurre gli elementi costitutivi e costruttivi in entità che il computer possa riconoscere e gestire. II processo implica la parametrizzazione degli elementi di base che determinano il risultato finale, rendendo possibile la modificazione digitale di forma e dimensioni e facilitando lo studio di proprietà, funzionalità e producibilità dell'oggetto. Tramite Grasshopper, editor visuale di algoritmi associato a Rhino (McNeel), sono stati definiti i parametri che controllano elementi, movimenti e ricorsività dei merletti semplici, poi assemblabili in elementi articolati.

L'intreccio base di 2 o più fili è ottenuto suddividendo una serie $L$ di circonferenze in 6 punti noti. Questi diventano i punti di controllo di una curva spline di interpolazione, definita da una funzione polinomiale di $3^{\circ}$ grado capace di mantenere, - per ogni coppia di punti, la continuità di posizione e tangenza che caratterizza il comportamento fisico della fibra tessile, simulando l'andamento elicoidale dei fili intrecciati e controllando i parametri che determinano le diverse tipologie di intreccio: spessore, giri e passo dell'elica (fig. 8).

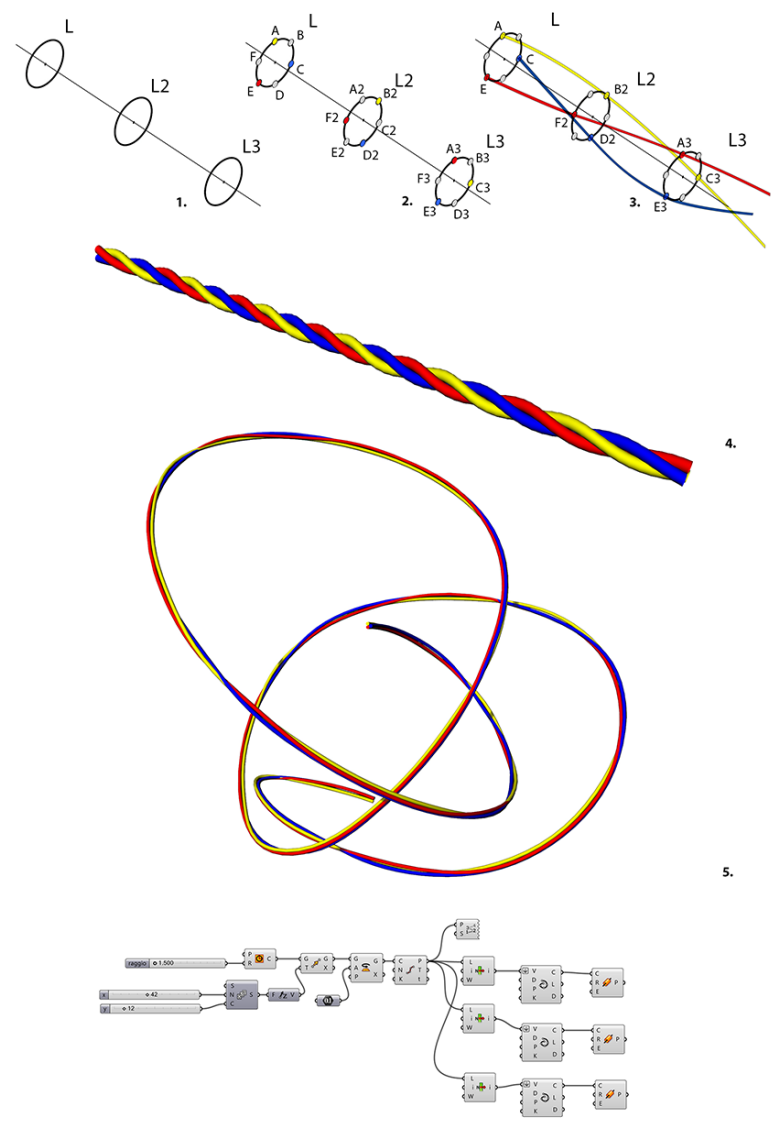


Degli operatori logici booleani di negazione, legati ai punti A, B, C, D, E, F garantiscono la non compenetrazione delle superfici e limitano il variare dello spessore del filo sino al punto di tangenza, a prescindere dal numero di fili.

L'algoritmo che descrive questo intreccio sfrutta le proprietà precedentemente descritte della curva spline di interpolazione, vincolata agli estremi della curva $A B$ e al punto $V$, proiezione del punto $M$ nel piano $X Z$, che giace sul segmento $A B$ appartenete a $X Y$. Rendendo $M$ una variabile compresa tra i valori della lunghezza $A B$ e $M V$ una variabile in un intervallo compreso tra 0 e $\infty$ è possibile modificare le caratteristiche morfologiche della curva. Modificando la curva su cui giacciono le circonferenze generatrici è possibile ottenere le geometrie ricercate.

La rototraslazione rispetto al punto A crea una sinusoide le cui onde sono vincolate ai punti variabili $\mathrm{M}$ e $\mathrm{V}$ e alla simmetria stessa. Con altre due traslazioni per simmetria è possibile ottenere l'unità base dell'armatura, ovvero l'intreccio sinusoidale tra trama (fig. 9) e ordito del merletto milanese.

Fig. 9. Algoritmo di

definizione dell'armatura: I) spline di interpolazione passante per i punti AVB.; 2) rototraslazione rispetto al punto $\mathrm{A}$ degli elementi geometrici ad ottenere una sinusoide dove MV e MIVI

controllano le altezze dell'onda e $B \mid A B$ la lunghezza: 3) la curva diventa diventa la generatrice cuica per una sezione circolare che defnisce la 4) 4) L parametrizzazione di M e Ml permette la modifica della morfologia simulando il comportamento dei tessili; 5, 6) ulteriori traslazioni per simmetria assiali definiscono il modulo base che può essere replicato indefinitamente.
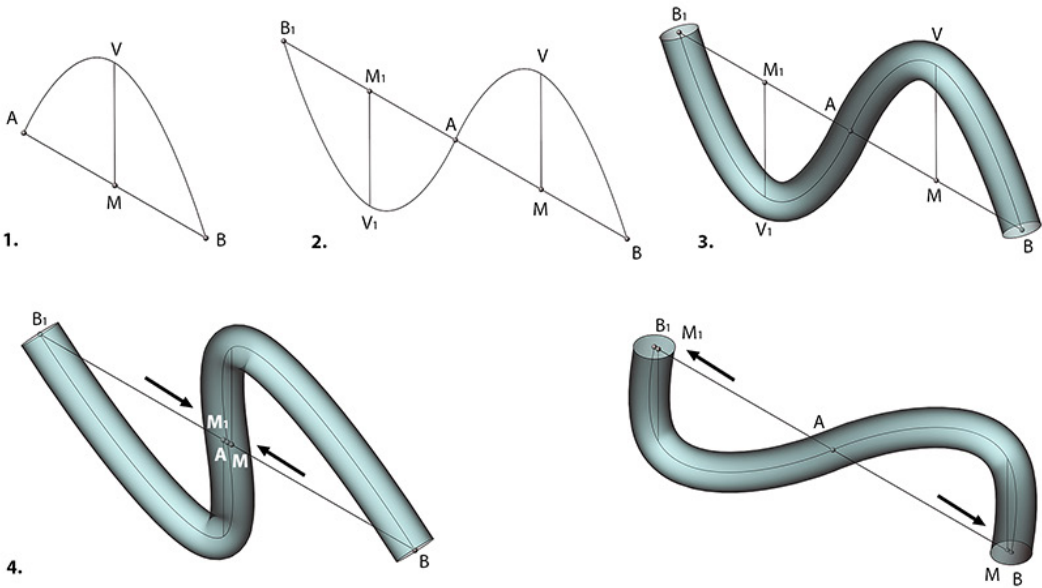

5.
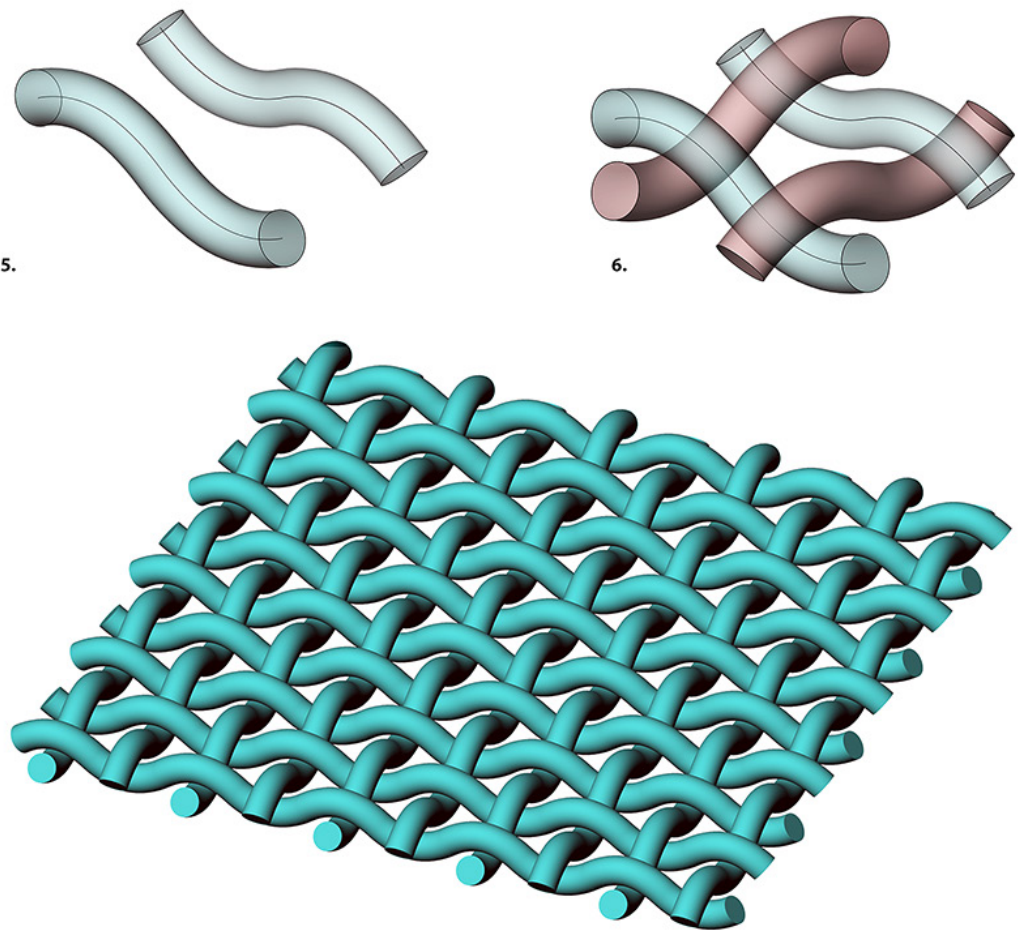
Tramite variazione dei parametri ed estensione dei caratteri comuni, la scrittura algoritmica generalizza la totalità dei casi possibili. Si possono creare strutture in trama, in catena (fig. 10) o tridimensionali e quest'ultime, sinora poco indagate per la complessità produttiva e morfologica, presentano proprietà strutturali interessanti anche per settori diversi dal tessile (fig. I I ). L'elasticità strutturale degli intrecci, che non dipende solo dal materiale, permette loro di agire come molle e per questo gli sforzi sono assorbiti a livello strutturale incidendo in misura minore sul materiale.

La possibilità di controllare con il disegno computazionale la configurazione del filato, in sinergia con processi produttivi altamente automatizzati che possono conferire ai materiali nuove prestazioni di leggerezza e resistenza, offre prospettive applicative interessanti per architettura e design, ma anche in campo aerospaziale o medicale.
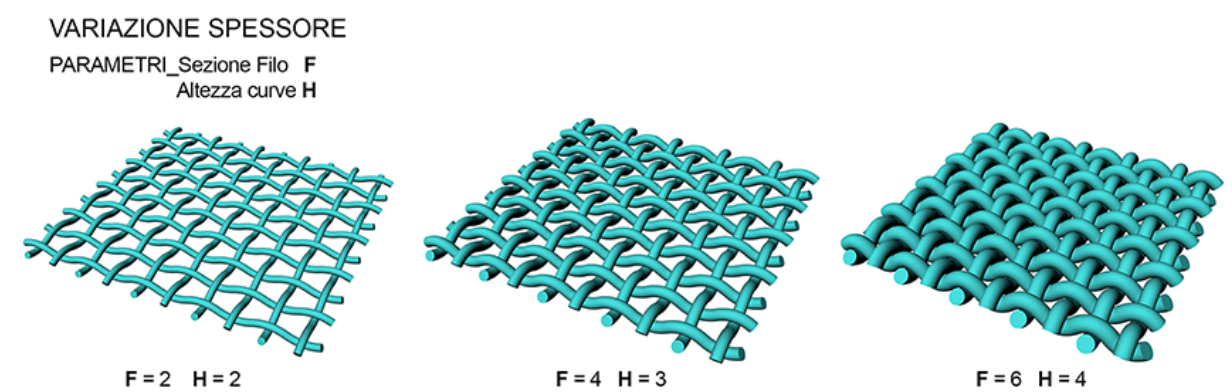

VARIAZIONE ORDITO PARAMETRI_Posizione Filo Pf

$\mathbf{P f}=0$

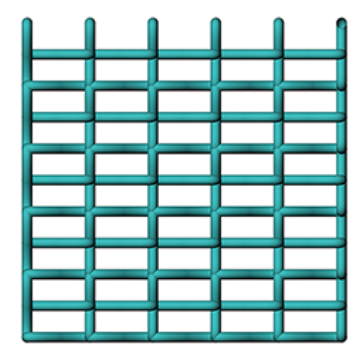

Bvebsebsebsebio

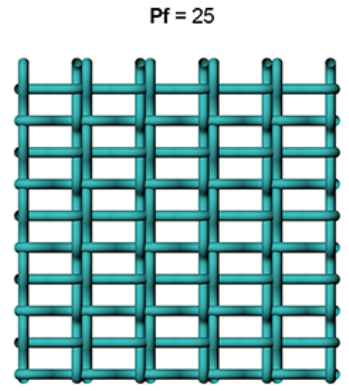

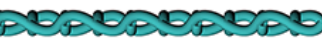

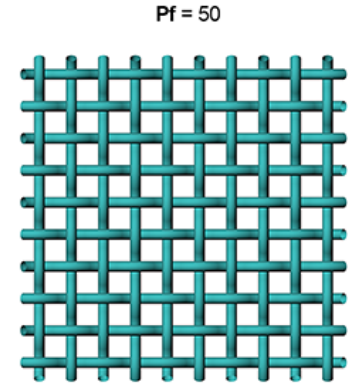

कणn 00000
Fig. 10. Modificando i diversi parametri è possibile ottenere delle variazioni morfologiche e della densità di tramatura. I parametri sono tra loro indipendenti e possono essere modificati a

piacere per ottenere la morfologia desiderata.
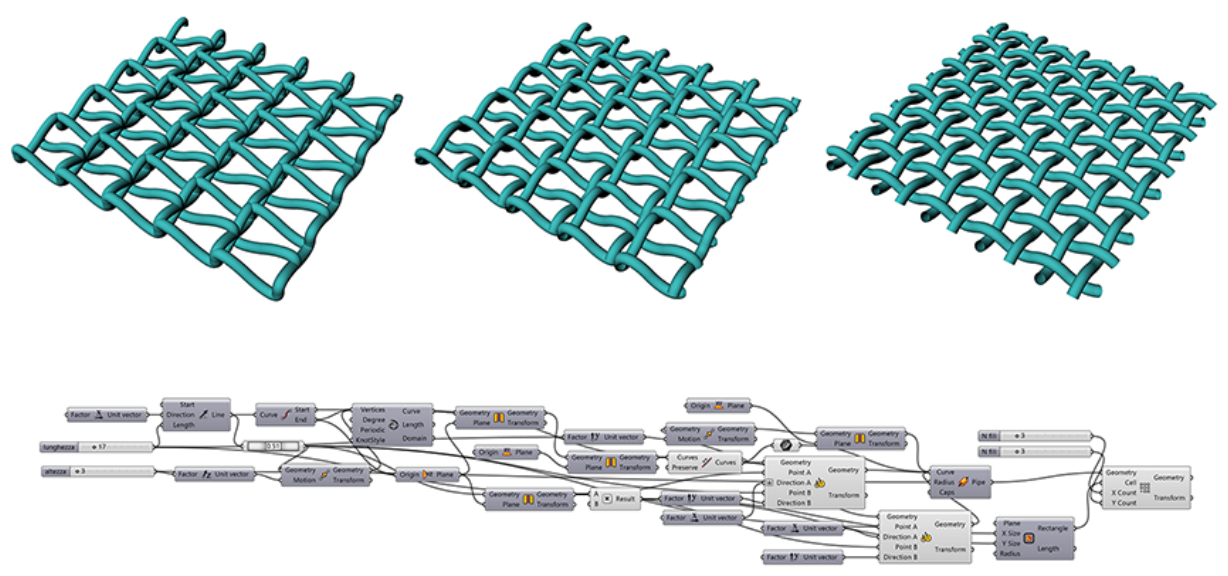

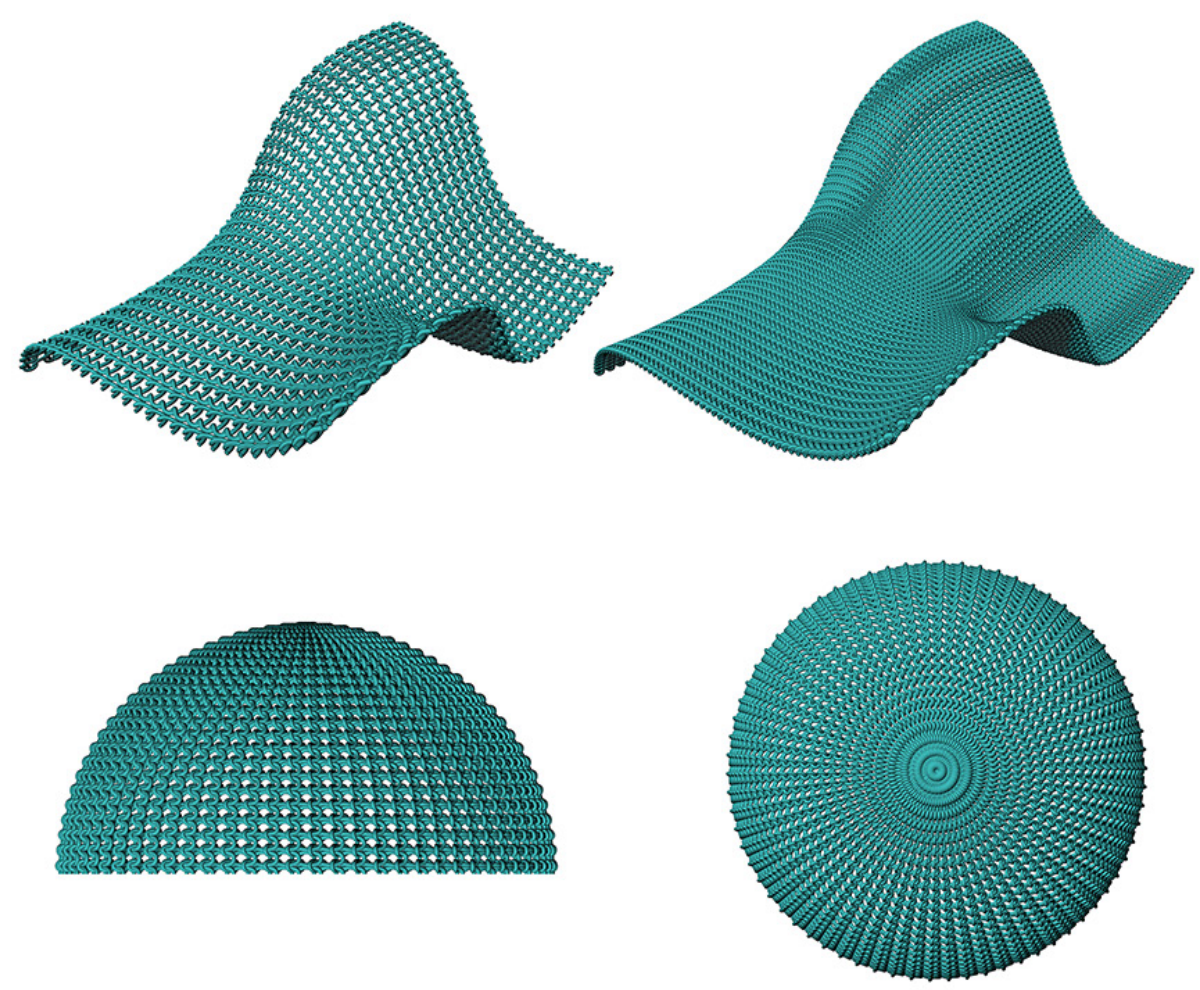

Fig. II. Studi tridimen-

sionali per l'adattamento

geometrico della trama

per una superficie strana

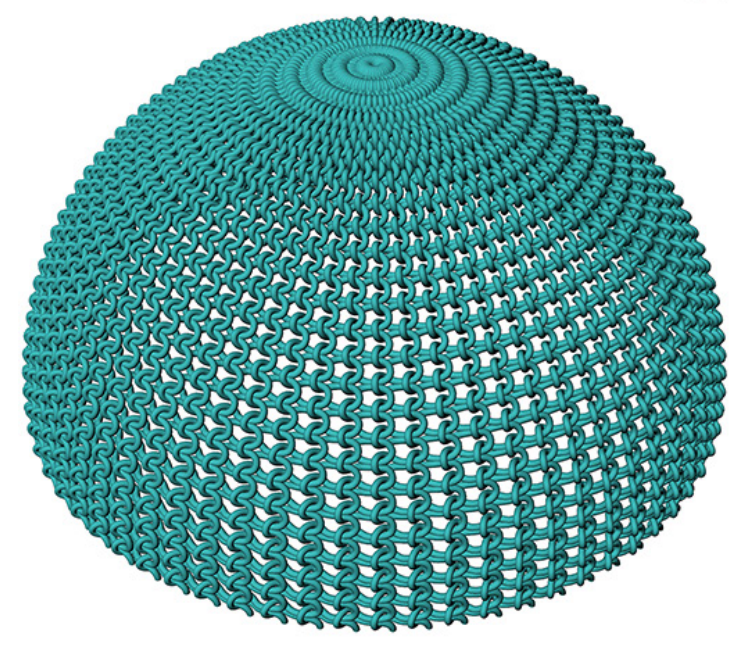



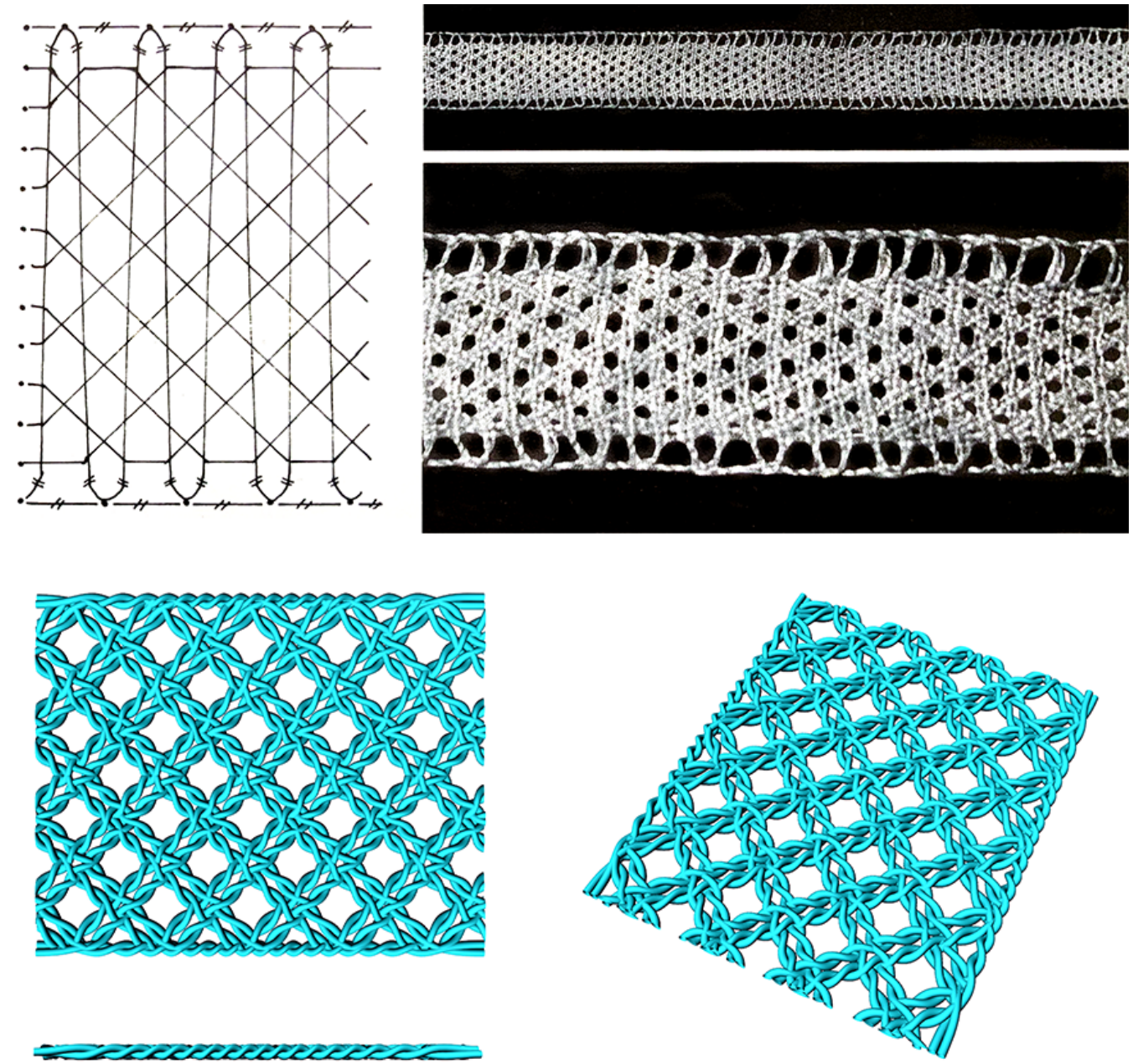

Fig. 12. Ricostruzione parziale di un nastrino a punto canestro.

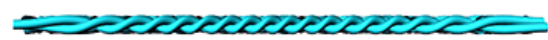

\section{Conclusione. Pizzi e nuovi materiali}

Questo è il primo risultato di una ricerca in fieri, che si pone l'obbiettivo di introdurre strumenti parametrici per la valorizzazione di arti e lavorazioni antiche. Il controllo digitale della geometria favorisce la diffusione di un patrimonio culturale passato come modello per la creazione di nuovi materiali, strutture o prodotti con caratteristiche innovative di leggerezza, permeabilità e resistenza.

Tecniche antiche insieme a strumenti attuali consentono di reinterpretare il merletto mediante applicazioni non solo estetiche ma strutturali, poiché - come insegna Semper - esiste un indissolubile nesso biunivoco tra materiale e tecnica di lavorazione. Infine, la manipolazione attraverso i nuovi strumenti di progettazione e produzione dei parametri formali, come la variazione della sezione del 'filo' o della grandezza della 'legatura', permette soluzioni prima impossibili [I].

[I] Sebbene il contributo sia stato concepito congiuntamente, Michela Rossi è autore del paragrafo 'Le premesse teoriche'; Valentina Marchetti del paragrafo 'La tradizione e la rilettura novecentesca' e delle relative immagini; Sara Conte del paragrafo 'll tombolo e la tecnica lombarda del merletto milanese' e delle relative immagini; Giorgio Buratti del paragrafo 'Merletti digitali' e delle relative immagini. Le conclusioni sono state redatte congiuntamente. 


\section{Riferimenti bibliografici}

Bouquet Luigi (1942). La scuola d'arte di Cantù. Firenze.

Guglielmetti llaria (20I5). Cultural Design: un tentativo interdisciplinare sperimentato nel progetto Design al tombolo. In Antropologia, vol. 2, n. 2, pp. |4|-|56.

II girovago (1943). La scuola di Cantù. In Fili, n. I I3, maggio 1943, p. 3.

Jourdain Margaret (1905). The Lace Collection of Mr. Arthur Blackborne. Part IV - Milanese Laces. In The Burlington Magazine for Connoisseurs, vol. 6, n. 23, pp. 384-385, 388-39I, 393.

Kuster Rosselli Emilia (194I). Stile nel ricamo. In Stile, n. 4, pp. 66, 67.

Mottola Molfino Alessandra (1984). Merletti lombardi. In Davanzo Poli Doretta (a cura di). Cinque secoli di merletti europei: i capolavori. Burano: Consorzio Merletti Burano, pp. 33-39.

Nicoletti Marco (2008), Tomaso Buzzi e il nuovo merletto d'arte. In CORA. Rivista di Artigianato artistico, Moda, Costume e Tradizioni, n. 2, maggio 2008

Pallise Bury (1902). History of Lace. New York: Margaret Jourdain and Alice Dryden editors.

Ponti Gio (1939). Per l'affermazione delle industrie femminili italiane. In Domus, n. I39, pp. 65-66.

Read Patricia, Kindcaid Lucy (1988). Milanese Lace. An introduction. London: Batsford book.

Read Patricia, Kindcaid Lucy (1994). New Braids and Designs in Milanese Lace. London: Batsford Book.

Rizzini Maria Luisa (1994). Complessi intrecci. I merletti di Cantù tra Settecento e Novecento. In Terraneo Alfio (a cura di). Merletti a Cantù. Cultura e tradizione di una comunità tra il secolo XVIII e XX. Catalogo della mostra. Cantù, Palazzo comunale, 18 settembre - 3 ottobre 1993. Cantù 1994.

Semper Gottfried ( 1860). Der Stil in der technischen und tektonischen Kunsten oder praktische Ästhetik. (Trad. it. parziale, Lo stile nelle arti tecniche e tettoniche o estetica pratica. Bari: Laterza, 1992).

Yi Li (2007). Computational Textile Bioengineering. In Xianyi Zeng, Yi Li, Da Ruan (eds.) Computational Textile. Berlino: Springer, pp. 203-221.

\section{Autori}

Sara Conte, Politecnico di Milano, sara.conte@polimi.it

Michela Rossi, Politecnico di Milano, michela.rossi@polimi.it;

Valentina Marchetti, Politecnico di Milano, valentina.marchetti@polimi.it

Giorgio Buratti, Politecnico di Milano, giorgio.buratti@polimi.it

Per citare questo capitolo: Conte Sara, Rossi Michela, Marchetti Valentina,Buratti Giorgio (2020). Legature, intrecci e merletti. Le strutture tessili/ Bindings, weaves and lace. The textile structures. In Arena A., Arena M., Brandolino R.G., Colistra D., Ginex G., Mediati D., Nucifora S., Raffa P. (a cura di). Connettere. Un disegno per annodare e tessere. Atti del $42^{\circ}$ Convegno Internazionale dei Docenti delle Discipline della Rappresentazionel Connecting. Drawing for weaving relationships. Proceedings of the 42th International Conference of Representation Disciplines Teachers. Milano: FrancoAngeli, pp. 342-367. 


\title{
Bindings, Weaves and Lace. The Textile Structures
}

\author{
Sara Conte \\ Michela Rossi \\ Valentina Marchetti \\ Giorgio Buratti
}

Abstract

The connection of the artefacts' parts is one the fundamental problem in the project filed. In this sense, the weaving art present interesting aspects for the design and architecture fields, which show, considering the effects of the latest digital revolution, the topicality of Semper's statements in the classification of materials and construction techniques.

Starting from the study of the state of the art and traditional techniques of making Milanese lace, the research's aim is to digitize and parameterize the construction process. The enhancement of the traditional technique is aimed at the productive reinvention applied to the design of new structural materials, rather than to the mere conservation of the historical artefact or its aesthetic adaptation to contemporary taste.

Generative modeling offers a valid solution for digitization and reinterpretation of the repeated lace production process. Once the basic elements, the intertwining or knotting movements and the complete cycle to be repeated are defined, it's possible to recreate the formal structure using the geometric control of shape and movement parameters. The experimentation shows how the new design and production tools offer the possibility to develop innovative solutions related to the manipulation of formal parameters.

Keywords

Knot, algorithm, connections, weaving, visual modeling.

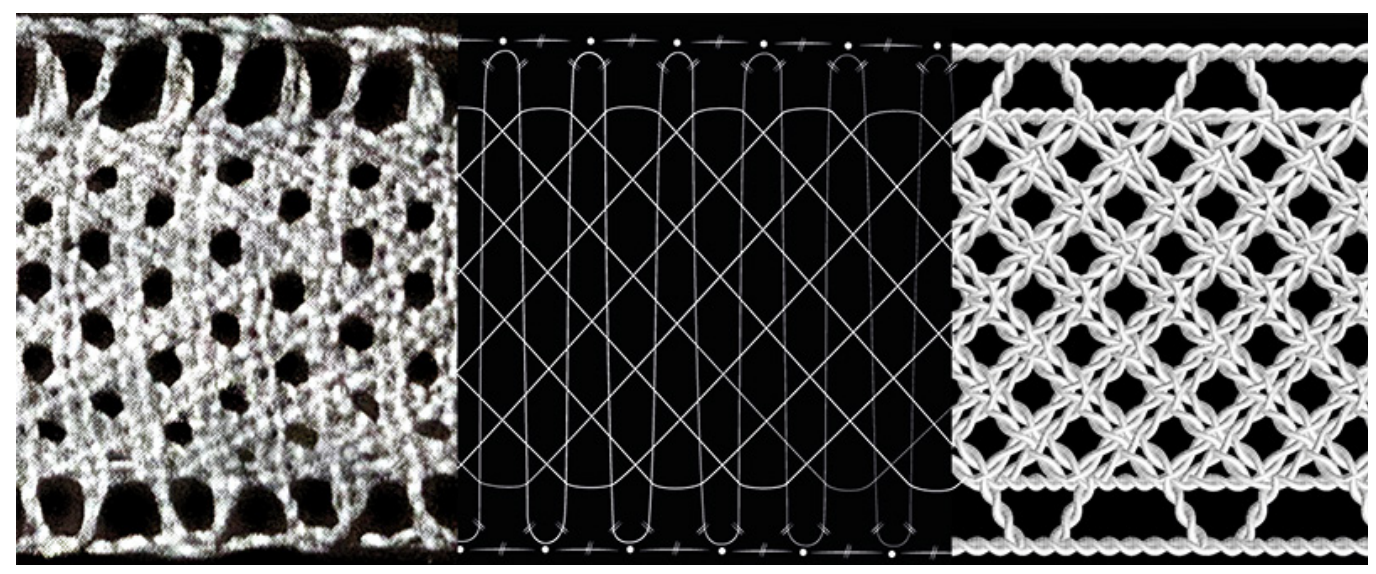




\section{Introduction. Theoretical premise}

Gottfried Semper argues that architecture has learned the rules of style from the shapes of everyday objects and today we can say that later, when industrial production replaced craftsmanship and the creator separated himself from the maker by requesting a preordained project, the latter returned them to design. The formal principles, which reinterpret laws and natural forces (symmetry, proportion, movement) are reflected in the three essential forms of weaving (festoon, edge, ribbon) characterized both clothing and architecture; in the architecture the principle of cladding, underlined by the common root of the words 'wand' and 'gewand' (wall and dress), is associated with the constructive principle that allows to create solidary spatial structures by binding small pieces.

The knot and the weave from which the button, the stitching, the weaving and the lace are born, are constructive and decorative elements together. The weave and lace elaborate the three-dimensional binding of the knot: a movement of the rope in space, which with windings or overlapping makes two stumps join together.The knot fixes the beginning of elongated structures (braids) which in turn can generate mats and fabrics, in which recursive regularity constitutes the main element of order and strength and allows the creation of characteristic designs. The articulation of the signs of the interlacing / knotting of multidirectional puffs determines on the surface a pattern that springs from the material and becomes form, combining the principles of construction and ornament.

The knot, the interweaving and the weaving develop the modular logic and the geometric rules of the surface, which together with the symmetries of the space constitute a theme of theoretical (mathematics) and design research. The geometric structures of the ornament lead us to the modular grids and the symmetries of the grids at the base of spatial constructions, and to the rules of flat and three-dimensional tessellation investigated by Escher, Fuller and Penrose, underlining the importance of the textile principle in architecture and its close relationship with the applied arts.

The innumerable scales of application of the formal principles of knot, weave and fabric and their re-elaboration aimed at application in multiple fields represent a precious source of references for the transposition to different scales and with the use of other materials. Today, the application of the tools of digital civilization and their great productive potential reaffirm the importance of primary construction principles, highlighting the importance of reviewing the concepts and elementary elements of weaving from the digital innovation perspective. From the sixteenth-century tradition of Milanese lace, of which traces remain in the lace of Cantù and in Gio Ponti's publications, begins a research that aims to experiment with structures generated by digital algorithms applicable to the creation of innovative and sustainable materials and artefacts reinterpreting an ancient art through digital tools and technologies.

\section{The tradition and the twentieth-century interpretation}

According to a Venetian legend, the first lace was made of sea foam and donated by sirens to a fisherman from the Burano island as a reward for his loyalty to his fiancée. The story reveals the origin of the lace, which evolves from fishing nets to become a decorative object: women in fact refine the plot by studying figures and refined geometries.

Between the end of the fifteenth and the beginning of the sixteenth century the needle lace of Burano spread in stately homes. Moreover, in the documents of property division between the sisters Angela and Ippolita Sforza Visconti (1493), the term 'tarnete' is used to indicate braids, lace and trimmings, testifying their presence also in the Milanese area and since I 584 lace is among the teachings of the University of Embroiderers of Milan. In the second half of the seventeenth century the lace technique found wide diffusion thanks to the establishment, in the monastery of Santa Maria in Cantù, of teaching the use of bobbin lace to girls' groups. Then, this practice and the Cantù technique spread to various schools including La Regia scuola d'arte applicata allindustria locale founded in 1882. 
After the setback caused by the First World War and in opposition to the spread of machine-made lace, craft and industrial activities were relaunched by ENAPI and soon textile works became part of the biennali di Monza and then of the triennali, attracting the attention of various architects including Gio Ponti. Domus, Stile and Fili, founded in 1934 by Emilia Kuster Rosselli, contributed significantly to the diffusion and modernization of lace. Domus will provide accurate reviews of the section dedicated to lace and embroidery at the Triennale of 1933, promoting the preparation of the 1940 Triennale, born "con lo scopo preciso di realizzare [...] la più esauriente ed alta mostra moderna del ricamo, che siasi mai vista in Italia" [Ponti 1939, p. 16]. Since 1928 various examples of 'modern' lace have been published, including those designed by the architect G. Wenter Marini, director of the Scuola canturina del mobile e del merletto since 1931. The research of the '30s focused on abstraction and geometrization of the design, without significant changes in terms of material; only from the end of the "50s, after the setback of the war, we see on the one hand the spread of lace and doilies made of plastic, where the innovation consists only in the application of the new material, and on the other hand there are diversified experiments that reinterpret the traditional practical technique departing from it. In 1965 Carla Accardi's La Tenda created a 3D environment in sicofoil, enriched by a dense pattern of graphic signs, which recalls the traditional weaving technique reinterpreted through graphics and colour. Other interesting works are developed by Franca Sonnino starting from the second half of the 70s, where the weaving of iron wire and cotton thread recreate three-dimensional books, building elements such as bricks, mosaics or abstract three-dimensional representations of architecture.

Since the early 1990s, initiatives to safeguard the lace tradition have proliferated, such as the Internationale del Merletto di Cantù and the related Merletti e Design, which see the collaboration between artists, architects, designers and lacemakers to create innovative projects that enhance the craftsmanship, including it in the research of contemporary design [Guglielmetti 20 I5], culminating with the candidacy of the same for inclusion in the list of Intangible Cultural Heritage of UNESCO. In the last 10 years the recovery of traditional techniques and lace aesthetics has been combined with new technologies. Serena Confalonieri presents in 2014 two lamps that exploit 3D technologies reinterpreting the typical weaves of traditional Italian lace and goldsmithery in sintered polyamide; preordained and repeated patterns typical of lace are the basis of the architectural elements of the macro-installation of The Flying Mosque by Choi+Shine Architects in 2018 and finally Lisa Marks designs a bra for mastectomized women, in which algorithmic modeling generates a three-dimensional lace, able to adapt to any anatomical shape: the lace becomes structure.

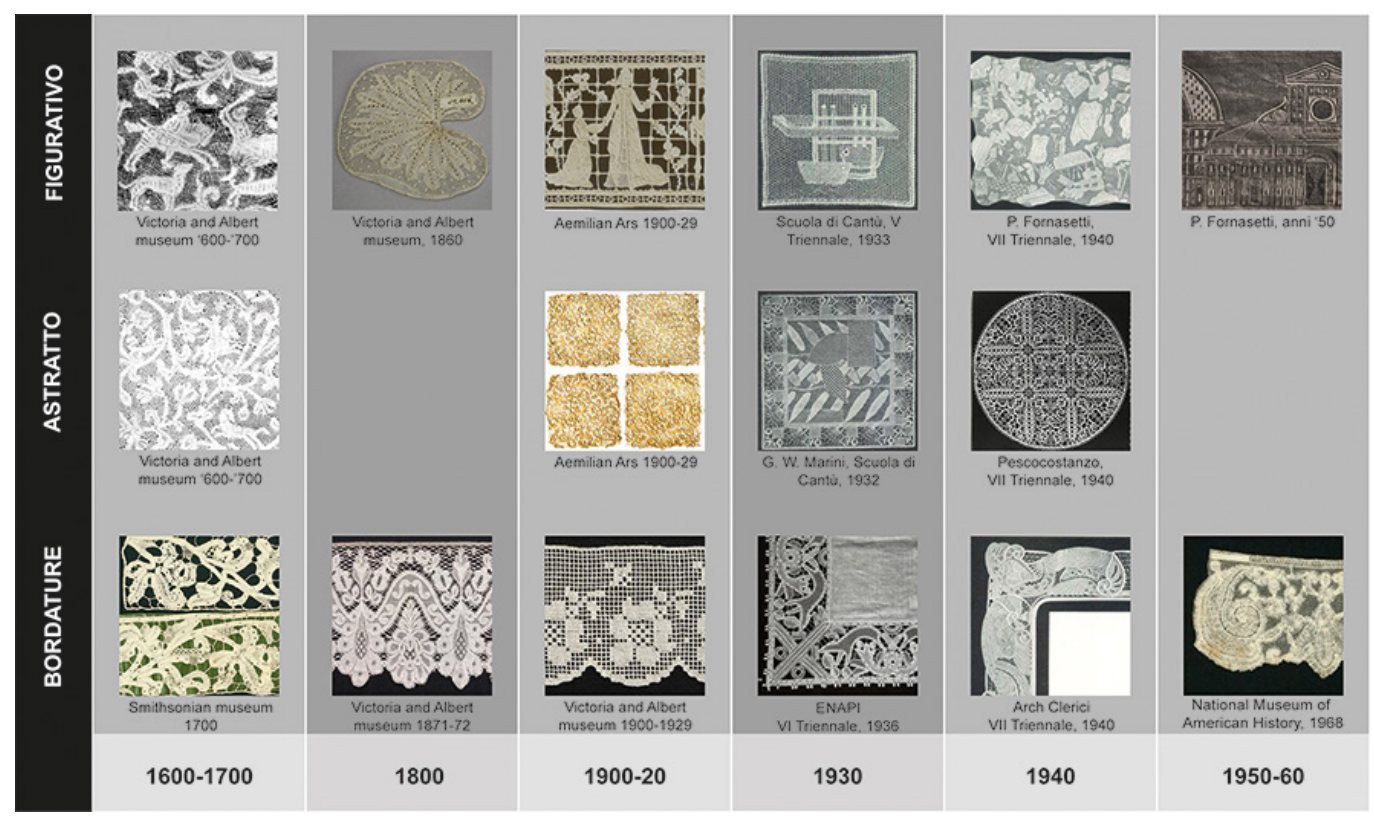




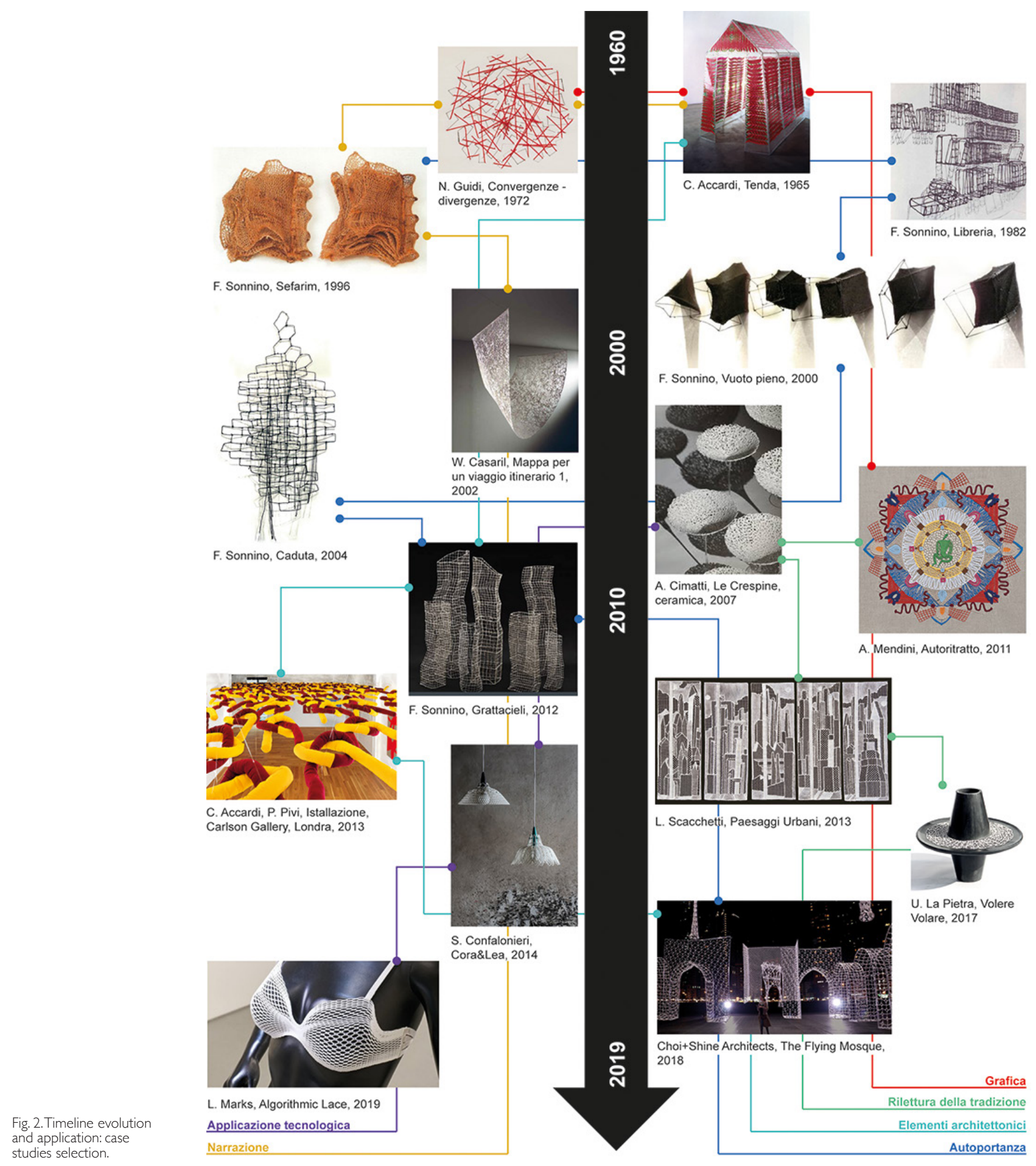




\section{The bobbing lace and the Lombard technique of Milanese lace}

The bobbing lace is a hand-made textile artwork, realized weaving a pair of few single threads partially wound on bobbins at the ends, commonly called fuselli. The weaving is worked on a cylindrical pillow padded with horsehair from which it takes its Italian name, tombolo, and to which it is fixed with pins. The pins also block the several passages during the work progress. The threads traditionally used are linen, silk, cotton, or more particular metallic threads, while in modern creations materials of all kinds are used. The bobbing lace is divided from the point of view of technique in:

- straight lace worked in both full and empty parts, called fillings, starting from a constant, sometimes large number of bobbins;

- continuous braid laces executed with a relatively few and constant number of bobbins, where the braid constitutes the full part of the work following a drawing of more or less elaborate volutes; when different parts approach each other they are joined by thread passages with the crochet hook or bobbins, called sewings or bars and with more complex filling patterns;

- part braid laces or discontinuous laces used instead a variable number of bobbins that increases or decreases during the work following the drawing; the full parts, called the braids, can be made by different people, and are joined with crochet hook and filled in the empty parts by fillings, bars or nets.

Since its origins in the 15th century, the main feature of the laces in the Lombard area, the Milanese lace or Milano stitch, was the braid lace or bisetta technique, which can be defined as the lace of the origins thanks to the presence of numerous drawings for this technique in one of the first and most popular laces model books Le Pompe printed in Venice in I 557. The weaving was compact and solid, fairly fast to execut, which determined its success over time. In the oldest laces that have come down to us, unlike Flemish needlace of that time, the braid was continuous and drew flowers and foliage with traditional ornamental motifs. Unlike needle lace, the Milanese did not require a bottom net to support the work and the motifs were joined together by bars during the work [Jourdain 1905]. From the middle of the seventeenth century, the bottom net appeared in the processing and not applied afterwards, with the same base points to fill the spaces with cobwebs, fish, jealousy or Valenciennes patterns.

The lace is made following defined technical-stylistic process: a drawer reports a drawing on cardboard creating the graphic design; then the trimmer, following the weaving trend, pricks the drawing that will serve as a path to the lacemaker for the realization of the braid (fig. 3).

Fig. 3. Schematic drawing of the pattern in which the cross bars indicate the number of turns of threads, the points indicate the pins, the circles the card; the pattern realized
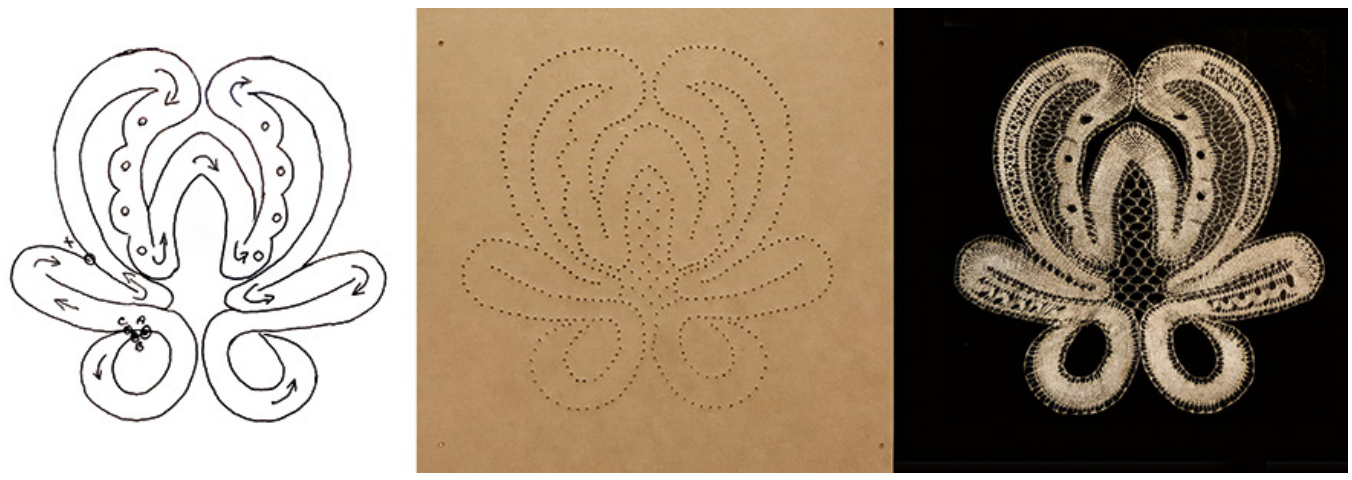

At the beginning of the drawing some pairs of bobbins, usually in odd numbers, called passives of down-rights, are hanged in line with pins, while the weavers pair (also called workers or leaders) positioned lower than the vertical ones, will be worked alternately from side to side creating the braid [Read, Kindcaid 1988]. All the basic stitches originate from the use of two pairs of bobbins, a worker and a passive, working with turn movements, exchanging the 
Fig. 4. Three movements of the cloth stitch or

whole stitch $1 / \mathrm{G} / \mathrm{l}$ a) two pairs of bobbins b) the second thread of the

left pair crosses the first thread of the right pair c) at the same time turn position between the second thread and first thread of the left pair and between the second thread and first thread of the right pair d) the

second thread of the

left pair crosses the first thread of the right pair.
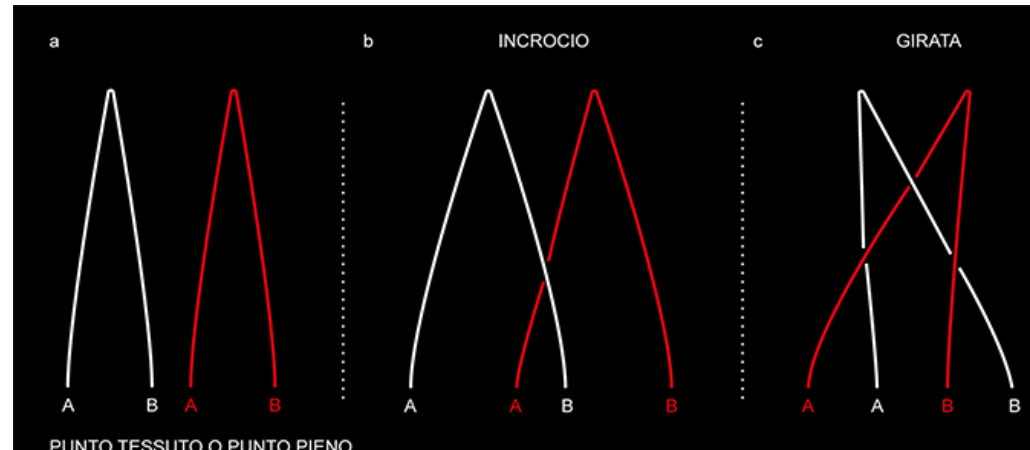

d INCROCIO

PUNTO TESSUTO O PUNTO PIENO

Fig. 5. Two movements of the half stitch $\mathrm{G} / \mathrm{l}$ a) two pairs of bobbins $b$ ) at the same time turn position between the second

thread and first thread of the left pair and between the second thread and

first thread of right pair c)

the second thread of the

left pair crosses the first

left pair crosses the first

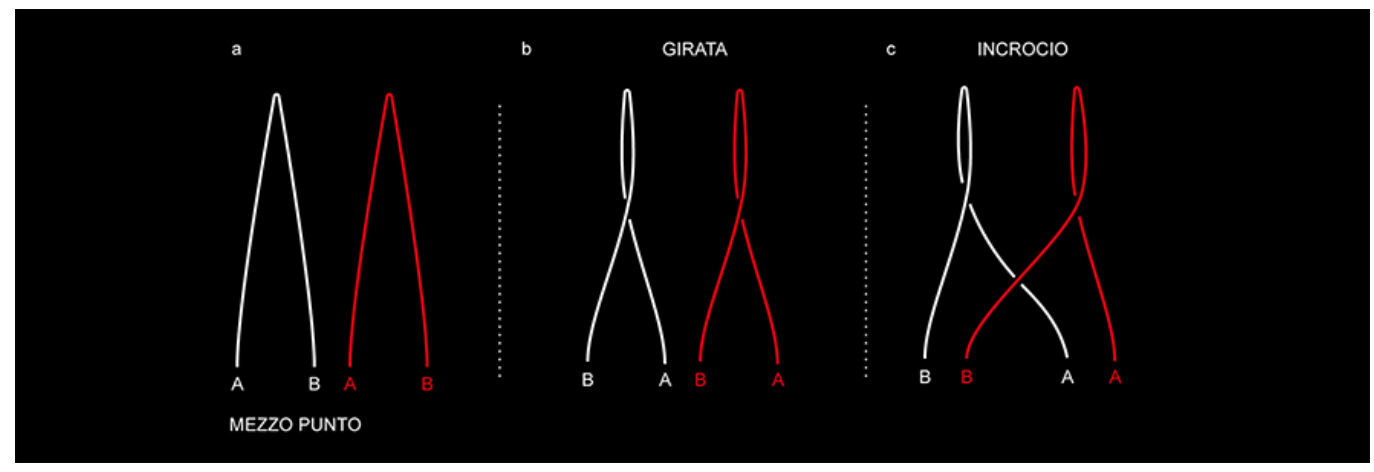

Fig. 6. Five movements of the turning stitch $1 / \mathrm{G} / / / \mathrm{G} / \mathrm{l}$

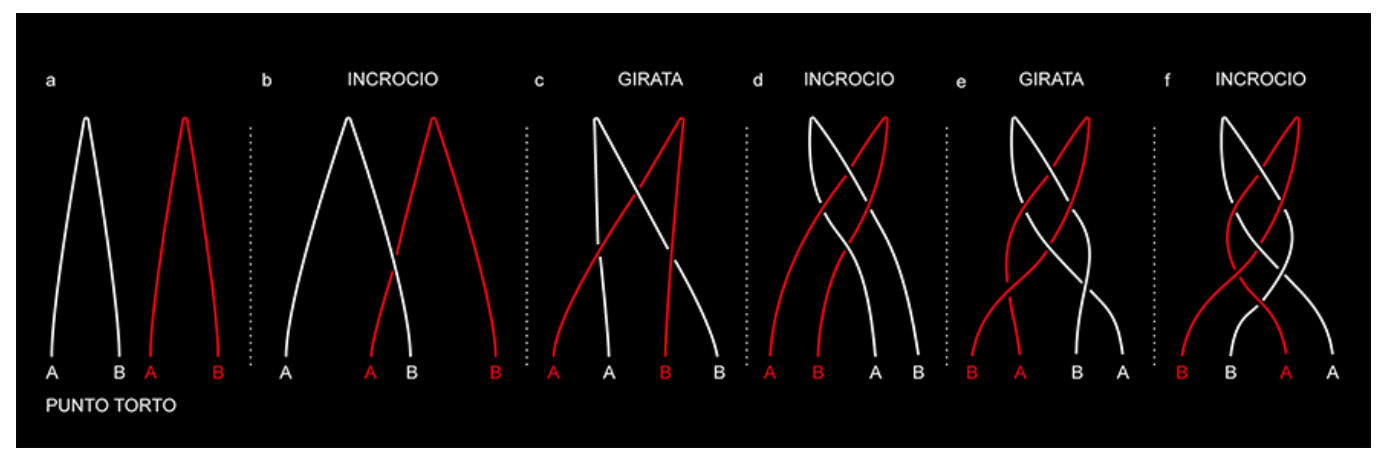


position of the threads in the same pair, and cross, the position exchange between the side by side threads of two different pairs (figs. 4-7).

The combination and succession of codified sequences of cloth or whole stitch, half stitch and turning stitch with empty spaces give life in Milanese lace to a wide variety of patterns, about 80, compared to any other lace. The variety, the self-supporting characteristics of the fabric, the three-dimensionality of the decorative weaving process and the experiments in progress have allowed the study of an automated generation of a traditional braid [Read, Kindcaid 1994], favouring the application of these structures in various fields of design.

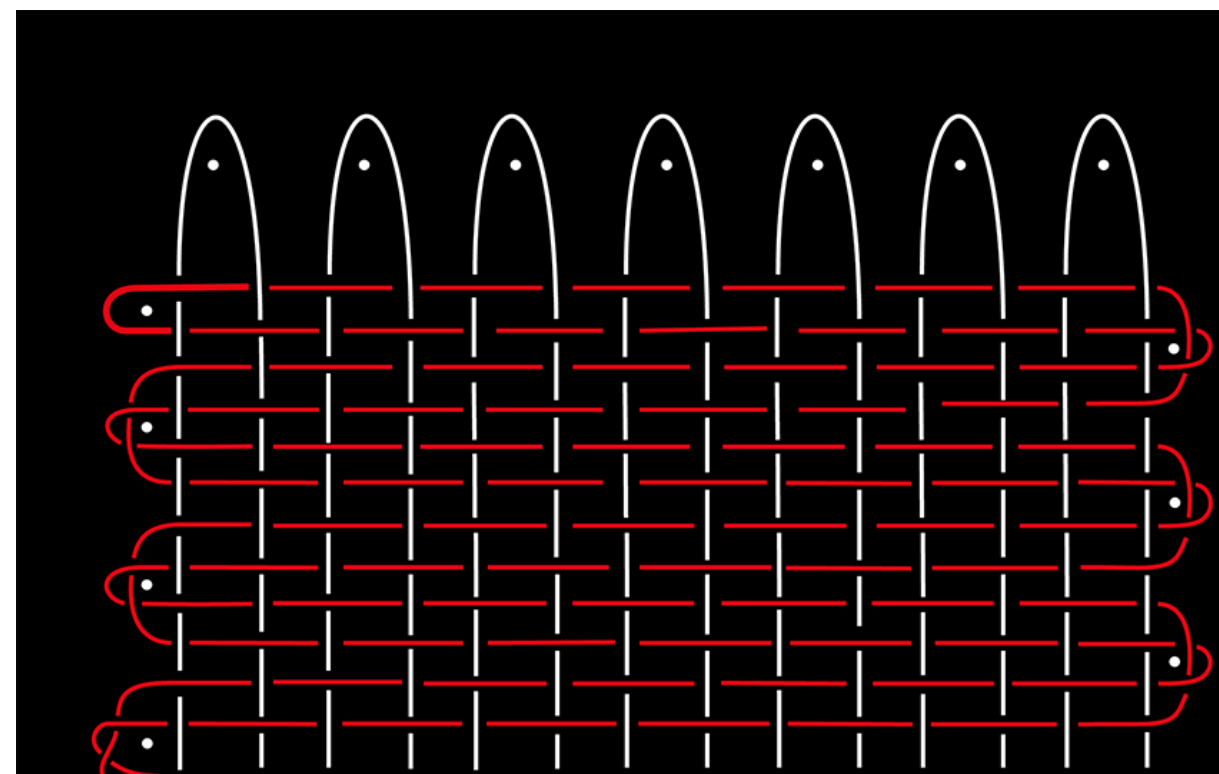

a_ SCHEMADI UN NASTRINO A 8 COPPIE IN PUNTO TESSUTO

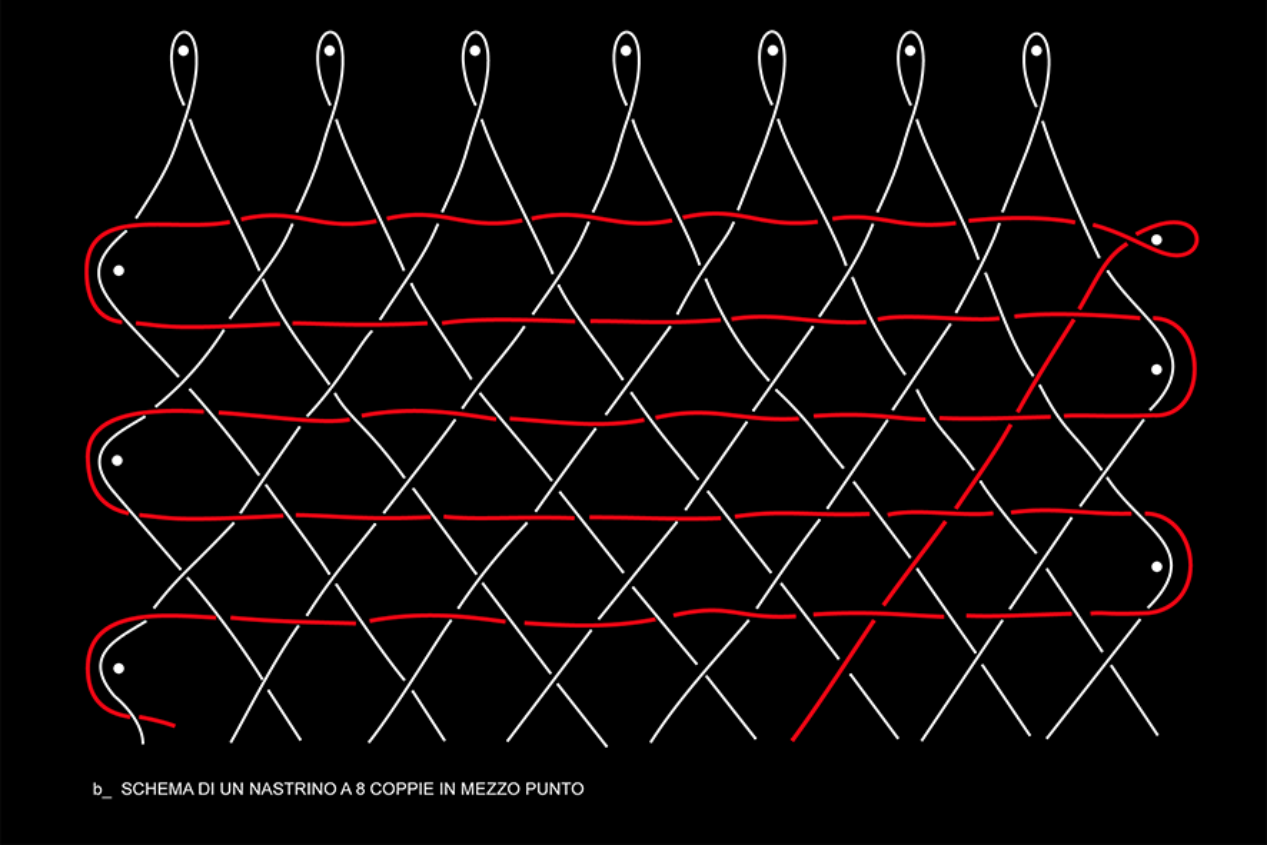




\section{Digital bobbin laces}

The binomial combination of computational processes and textile production has attracted the interest of the industrial and academic world since the invention (17th century) of the Jacquard loom, which allowed the automatic handling of single warp threads starting from perforated cartons to set more complex weaves than those that could be obtained by hand. The technology has given a considerable boost to the textile sector: computational textile [Xianyi et al. 2007], has allowed solutions capable of improving the properties of washability and elasticity by promoting new functions. The result is the current variety of advanced textiles whose properties derive from the synergy between innovative materials used and the study of the geometries that characterize the weave.

Representing textile morphologies through algorithms means understanding the combinations and sequences of characteristic knots, to translate the constituent and constructive elements into entities that the computer can recognize and manage. The process involves the parameterization of the basic elements that determine the final result, making possible the digital modification of shape and size and facilitating the study of properties, functionality and manufacturability of the object. Through Grasshopper, visual algorithm editor associated with Rhino (McNeel), the parameters that control elements, movements and recursiveness of simple lace, then assembled into articulated elements, have been defined.

The basic braiding of 2 or more wires is obtained by dividing an $L$ series of circumferences into 6 known points. These become the control points of an interpolation spline curve, defined by a 3rd degree polynomial function capable of maintaining, for each pair of points, the continuity of position and tangency that characterizes the physical behavior of the textile fiber, simulating the helical trend of the braided yarns and controlling the parameters that determine the different types of braiding: thickness, turns and pitch of the helix (fig. 8).

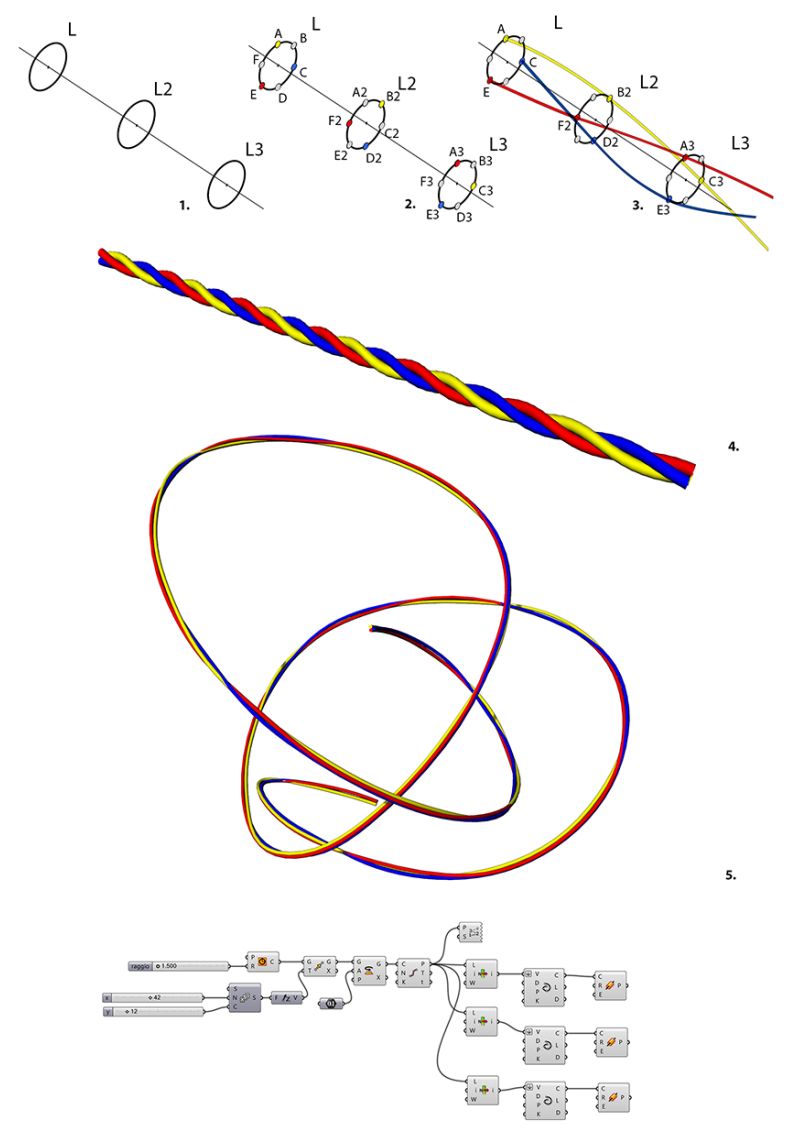


Logical Boolean denial operators, linked to points A, B, C, D, E, F, guarantee the non-interpenetration of the surfaces and limit the variation of the thread thickness up to the point of tangency, regardless of the number of threads.

The algorithm that describes this interweaving exploits the previously described properties of the interpolation spline curve, bound at the extremes of the curve $A B$ and at point $V$, projection of point $M$ in the $X Z$ plane, which lies on segment $A B$ belonging to $X Y$. By making $M$ a variable between the values of the length $A B$ and $M V$ a variable in a range between 0 and $\infty$ it is possible to modify the morphological characteristics of the curve. By modifying the curve on which the generating circumferences lie, it is possible to obtain the desired geometries.

The rototranslation with respect to point $A$ creates a sinusoid whose waves are bound to the variable points $M$ and $V$ and to the symmetry itself. With two other translations by symmetry it is possible to obtain the basic unit of the armature, i.e. the sinusoidal braiding between the weft (fig. 9) and the warp of the Milanese lace.

Fig. 9. Armor definition algorithm: I. Interpolation splines through the AVB points. 2. Rototranslation with respect to point A of the geometrica elements to obtain sinusoid where MV and MIVI control the wave heights and $B I A B$ wave becomes the guiding cones the guiding generator for a circular section that defines the cylindrical wire section. 4. The parameterization of $M$ and $M I$ allows the modification of the morphology by simulating the behavior of textiles. 5.6. Further translations by axial symmetry define the basic module that can be replicated indefinitely.
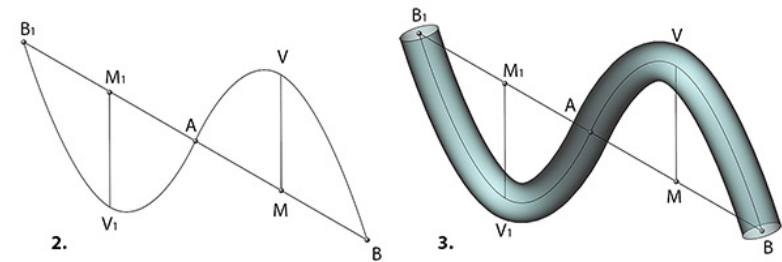

1.

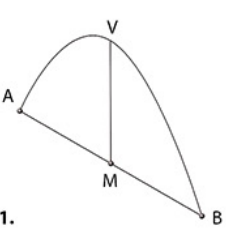

2.
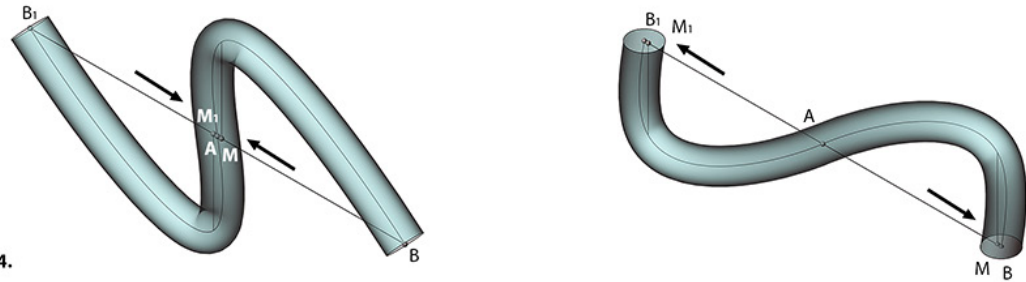

5.
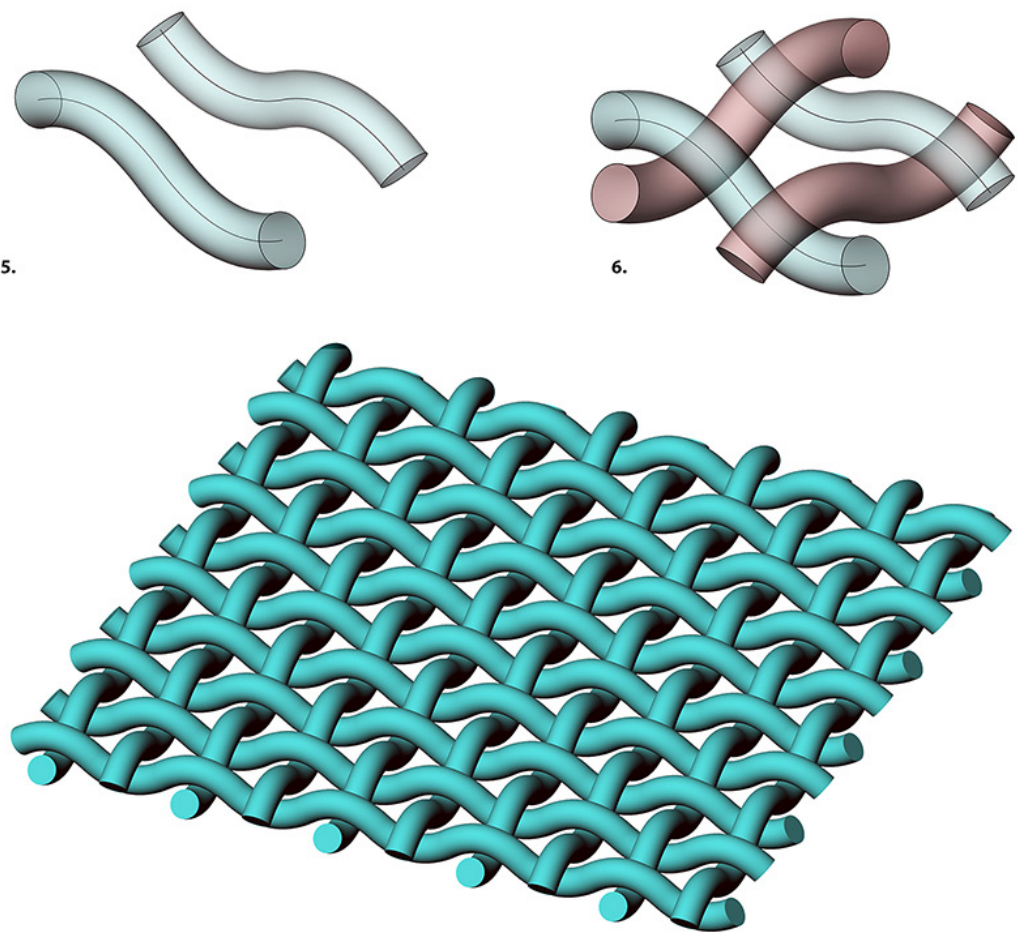
By changing the parameters and extending the common characters, the algorithmic writing generalizes the totality of possible cases. It is possible to create weft, chain (fig. I0) or three-dimensional structures and the latter, so far little investigated for the productive and morphological complexity, present interesting structural properties also for sectors other than textiles (fig. I I). The structural elasticity of the weaves, which does not depend only on the material, allows them to act as springs and for this reason the stresses are absorbed at a structural level affecting the material to a lesser extent.

The possibility to control with the computational design the yarn configuration, in synergy with highly automated production processes that can give materials new performances of lightness and resistance, offers interesting application perspectives for architecture and design, but also in aerospace or medical field.
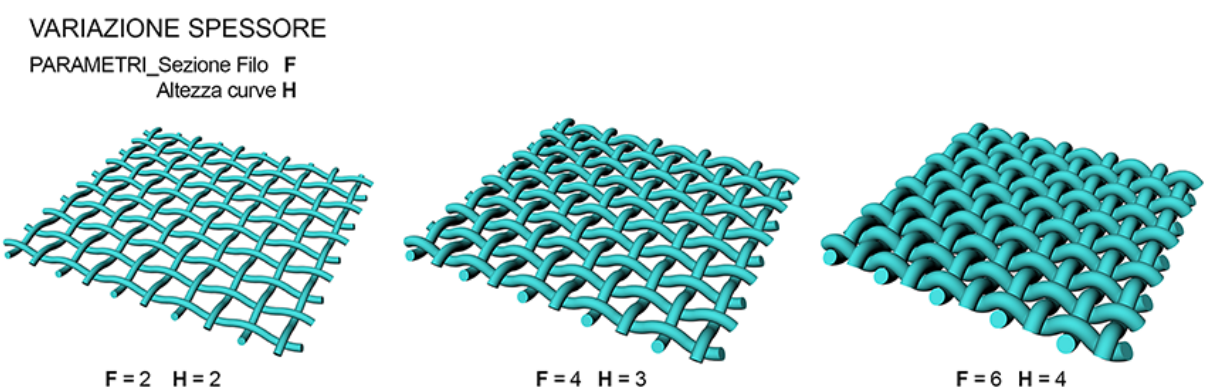

VARIAZIONE ORDITO PARAMETRI_Posizione Filo Pf

$\mathrm{Pf}=0$

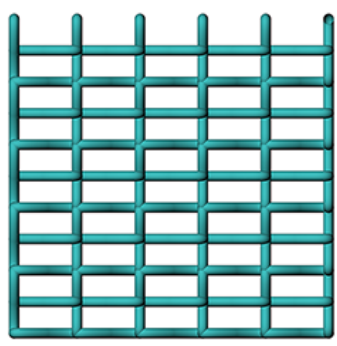

biebiebsebsebso
Pf $=25$

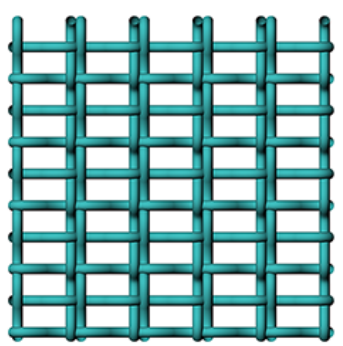

$\mathrm{Pf}=50$

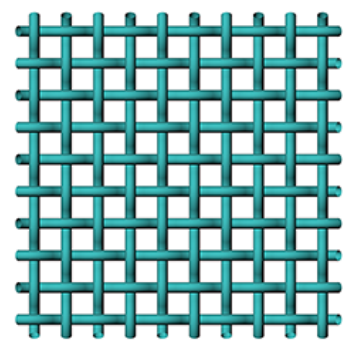

Fig. 10. By modifying the different parameters it is possible to obtain morphological variations and texture density. The parameters are independent from each other and can be modified at will to obtain the desired morphology
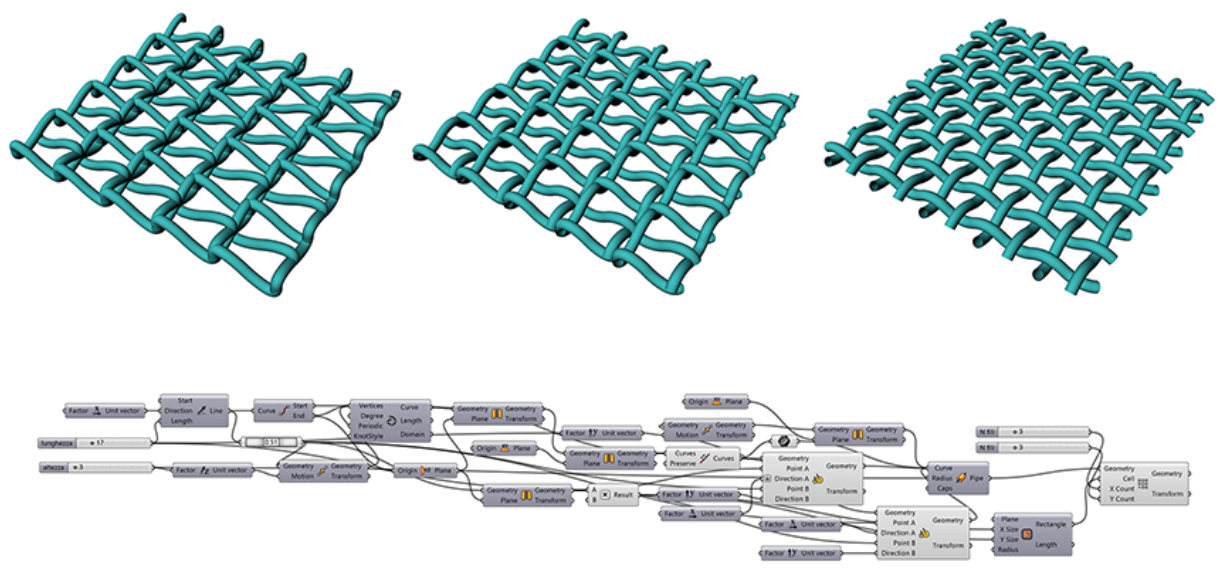

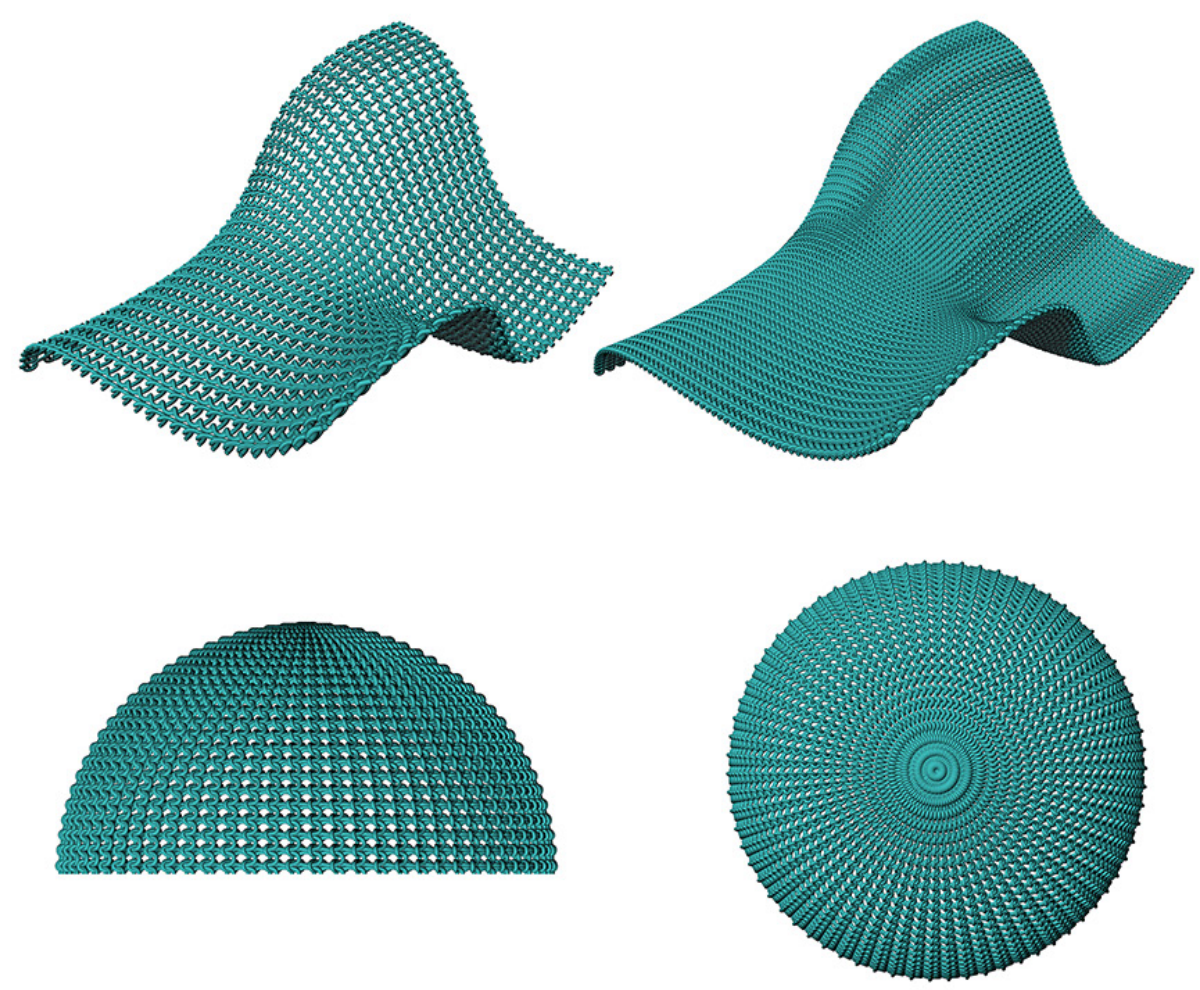

Fig. II.Three-dimensiona

studies for the geometric

adaptation of the weft fo

a strange surface and a

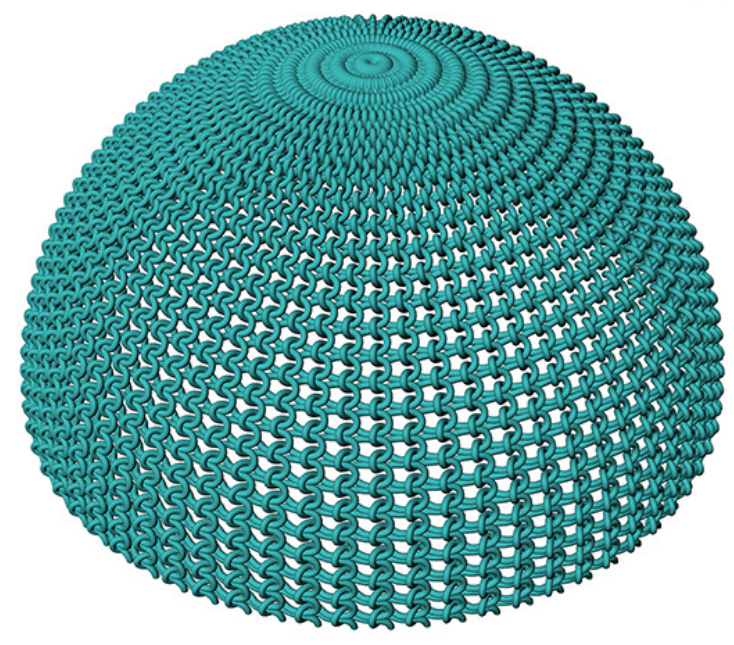



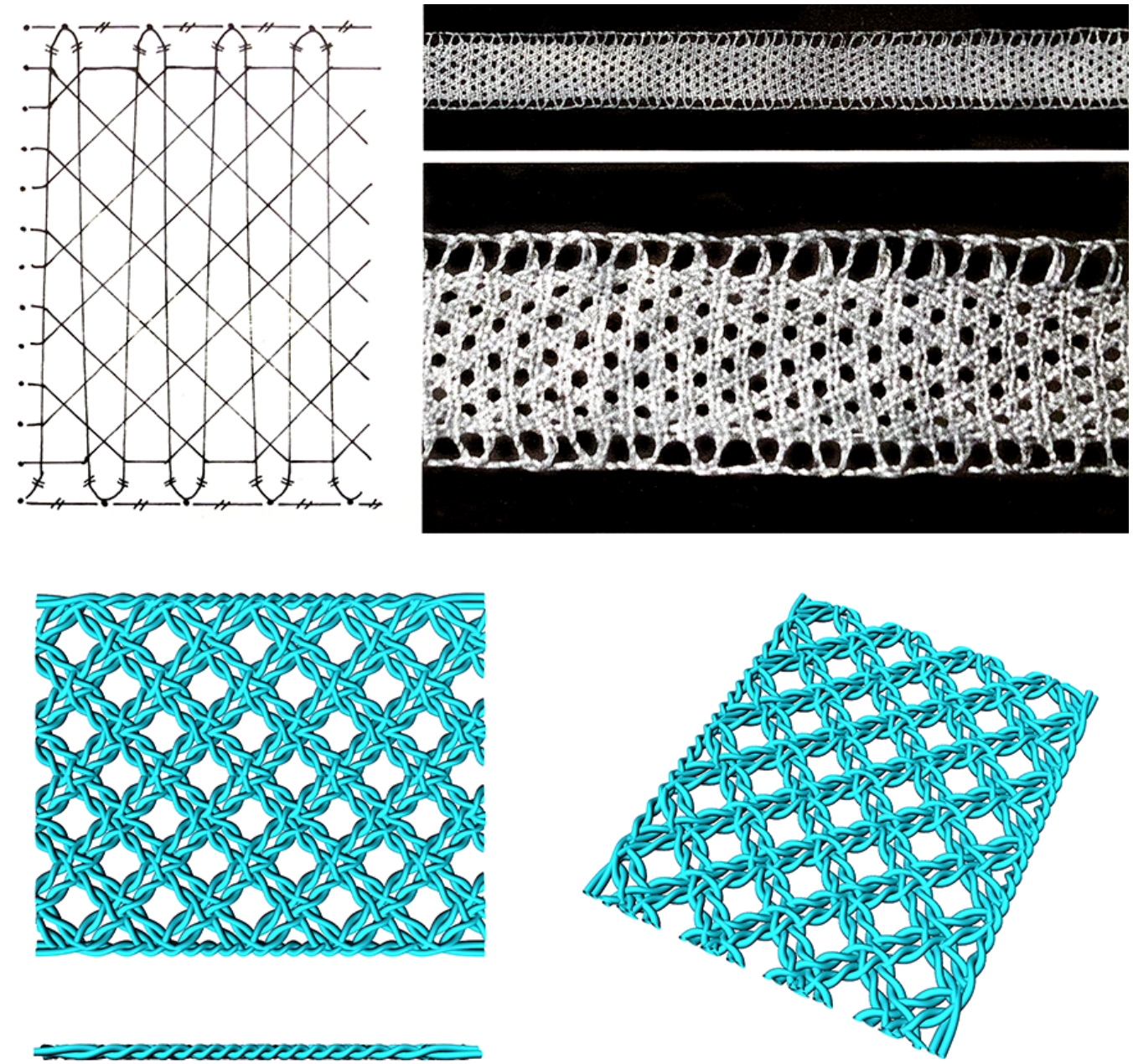

Fig. 12. Partial reconstruction
ave braid.

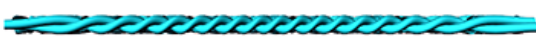

Conclusions. Lace and new materials

This is the first result of a research in progress, which aims to introduce parametric tools for the enhancement of ancient arts and crafts. The digital control of geometry favours the diffusion of a past cultural heritage as a model for the creation of new materials, structures or products with innovative characteristics of lightness, permeability and resistance.

Ancient techniques together with current tools allow to reinterpret bobbin lace through applications that are not only aesthetic but also structural, since -as Semper teaches - there is an indissoluble two-way link between material and working technique. Finally, the manipulation through the new design and production tools of formal parameters, such as the variation of the section of the 'thread' or the size of the 'binding', allows previously impossible solutions [I].

\section{Notes}

[I] Although the contribution was conceived jointly, Michela Rossi is the author of the paragraph 'Theoretical premise'; Valentina Marchetti of the paragraph 'The tradition and the twentieth-century interpretation' and the related images: Sara Conte of the paragraph 'The bobbing lace and the Lombard technique of Milanese lace' and the related images; Giorgio Buratti of the paragraph 'Digital bobbin laces' and the related images. The conclusions were drawn jointly. 


\section{References}

Bouquet Luigi (1942). La scuola d'arte di Cantù. Firenze.

Guglielmetti llaria (20I5). Cultural Design: un tentativo interdisciplinare sperimentato nel progetto Design al tombolo. In Antropologia, vol. 2, n. 2, pp. |4|-|56.

II girovago (1943). La scuola di Cantù. In Fili, n. I I3, maggio 1943, p. 3.

Jourdain Margaret (1905). The Lace Collection of Mr. Arthur Blackborne. Part IV - Milanese Laces. In The Burlington Magazine for Connoisseurs, vol. 6, n. 23, pp. 384-385, 388-39I, 393.

Kuster Rosselli Emilia (194I). Stile nel ricamo. In Stile, n. 4, pp. 66, 67.

Mottola Molfino Alessandra (1984). Merletti lombardi. In Davanzo Poli Doretta (a cura di). Cinque secoli di merletti europei: capolavori. Burano: Consorzio Merletti Burano, pp. 33-39.

Nicoletti Marco (2008), Tomaso Buzzi e il nuovo merletto d'arte. In CORA. Rivista di Artigianato artistico, Moda, Costume e Tradizioni, n. 2, maggio 2008

Pallise Bury (1902). History of Lace. New York: Margaret Jourdain and Alice Dryden editors.

Ponti Gio (1939). Per l'affermazione delle industrie femminili italiane. In Domus, n. I39, pp. 65-66.

Read Patricia, Kindcaid Lucy (1988). Milanese Lace. An introduction. London: Batsford book.

Read Patricia, Kindcaid Lucy (1994). New Braids and Designs in Milanese Lace. London: Batsford Book.

Rizzini Maria Luisa (1994). Complessi intrecci. I merletti di Cantù tra Settecento e Novecento. In Terraneo Alfio (a cura di). Merletti a Cantù. Cultura e tradizione di una comunità tra il secolo XVIII e XX. Catalogo della mostra. Cantù, Palazzo comunale, 18 settembre - 3 ottobre 1993. Cantù 1994.

Semper Gottfried ( 1860). Der Stil in der technischen und tektonischen Kunsten oder praktische Ästhetik. (Trad. it. parziale, Lo stile nelle arti tecniche e tettoniche o estetica pratica. Bari: Laterza, 1992).

Yi Li (2007). Computational Textile Bioengineering. In Xianyi Zeng, Yi Li, Da Ruan (eds.) Computational Textile. Berlino: Springer, pp. 203-221.

\section{Authors}

Sara Conte Politecnico di Milano, sara.conte@polimi.it

Michela Rossi, Politecnico di Milano, michela.rossi@polimi,it;

Valentina Marchetti, Politecnico di Milano, valentina.marchetti@polimi.it

Giorgio Buratti, Politecnico di Milano, giorgio.buratti@polimi.it

To cite this chapter. Conte Sara, Rossi Michela, Marchetti Valentina,Buratti Giorgio (2020). Legature, intrecci e merletti. Le strutture tessili/ Bindings, weaves and lace. The textile structures. In Arena A., Arena M., Brandolino R.G., Colistra D., Ginex G., Mediati D., Nucifora S., Raffa P. (a cura di). Connettere. Un disegno per annodare e tessere. Atti del $42^{\circ}$ Convegno Internazionale dei Docenti delle Discipline della Rappresentazione/Connecting. Drawing for weaving relationships. Proceedings of the 42th International Conference of Representation Disciplines Teachers. Milano: FrancoAngeli, pp. 342-367. 